\title{
Strengthening of Corroded RC Bridge Piers Subjected to Seismic Loads Using UHPFRC Jacketing
}

\author{
Heba A. Mohamed*, Mohamed Husain, Sayed Ahmed \\ Department of Structural Engineering, Faculty of Engineering, Zagazig University, Zagazig, Egypt
}

Email address:

hebawahbe $@$ yahoo.com (H. A. Mohamed)

${ }^{*}$ Corresponding author

\section{To cite this article:}

Heba A. Mohamed, Mohamed Husain, Sayed Ahmed. Strengthening of Corroded RC Bridge Piers Subjected to Seismic Loads Using UHPFRC Jacketing. American Journal of Construction and Building Materials. Vol. 4, No. 2, 2020, pp. 61-76.

doi: 10.11648/j.ajcbm.20200402.14

Received: November 5, 2020; Accepted: November 16, 2020; Published: November 24, 2020

\begin{abstract}
Corrosion of steel reinforcement is the main damage issue for the efficiency and performance of reinforced concrete (RC) bridge piers located in aggressive environments. In this study, the possibility of strengthening corroded RC bridge piers with high corrosion leveled by ultra-high performance fiber RC (UHPFRC) jacketing was investigated numerically. The model of nonlinear 3-D finite-element (FE) was constructed by using ANSYS software. The parameters of axial force ratio, longitudinal reinforcement ratio, aspect ratio, and transverse reinforcement ratio were studied to determine their effect on the lateral load resistance of strengthening corroded RC bridge piers. The verification carried out between the constructed FE and the experimental results of ten RC bridge piers in four experimental studies. The performance of RC bridge piers under cyclic lateral displacement and axial force was studied with different ratios. Finally, a practical model to calculate the lateral load resistance of corroded RC bridge piers was proposed. The results of this research suggest that this technique could be applied for existing concrete bridge exposed in the marine environment whereas, the concentration of corrosive chlorides are high and can also use for any shape of a column and this technique allows keeping the initial dimension of the column.
\end{abstract}

Keywords: Corrosion, Strengthening, Deterioration, Aspect Ratio, Lateral Displacement

\section{Introduction}

Research has been recently carried out to explain the nature of corrosion and its mechanisms. In addition, the purpose of most industrial studies on deterioration has been rehabilitation and repair of deteriorated components of civil infrastructure. On the other hand, a few investigations have been executed to evaluate the behavior of damaged reinforced concrete structures. The accurate estimation of the current load carrying capacity of a deteriorated reinforced concrete member can help in developing cost-effective rehabilitation methods [1].

Akkaya carried out the lateral cyclic loading test on 13 rectangular RC columns divided into three groups to study the seismic behavior of columns reinforced with plain and deformed bars under the influence of corrosion [2]. The mode of failure for columns with a high rate of corrosion was a fracture of starter bars. Ma et al. conducted cyclic loading tests on 13 circular RC columns under different rates of corrosion and axial compressive loads [3]. They indicated that high levels of corrosion and high axial loads led to the brittle failure of the column and cause stiffness, ductility, energy dissipation reduction furthermore poor hysteric response. Shihata examined eighteen reinforced concrete beams to study the effect of CFRP sheets on enhancing the bond strength of corroded lap splices [4]. Experimental results showed that longitudinal bars fail in the brittle way in the spliced region due to splitting and de-bonding of concrete cover. Ou et al. tested five large-scale beams under cyclic loading to investigate the cyclic performance of corroded beams [5]. The free end of the cantilever subjected to cyclic loading and the results concluded that because of transverse reinforcement rupture due to corrosion, longitudinal bars buckled and mode of failure transformed from flexural failure mode to flexural-shear one. Ran et al. investigated experimentally the behavior of strengthened corroded reinforce concrete columns by using carbon - fabric reinforced cementitious matrix (C-FRCM) under cyclic 
loading [6]. The test specimens were subjected to cyclic loading test after the occurrence of corrosion, where the axial compression with various ratios were taken into consideration. The results indicated that the use of C-FRCM can successfully enhance the strength, stiffness, energy dissipation capacity and ductility of the corroded RC columns. Haijun et al. [7] developed twelve reinforced concrete piers and exposed them to partially corroded to emulate intense corrosion in tidal and splash zones. The results demonstrated that there was a deterioration in piers' mechanical parameters as the corrosion increases, where the ductility factor, ultimate load and energy dissipation decreased by $21.47 \%, 10.69 \%$ and $57.46 \%$ respectively with $15.71 \%$ rebar mass loss for cyclic loading specimens.

Traditional jacketing exhibits some inconvenience, where the thickness of jacketing is governed by the cover of steel (external as well as internal cover), it is predominating higher than 70-100 mm, Fib Bulletin 24 [8]. Recently, a new technique of using thin jackets of high performance fiber reinforced concrete (HPFRC) has been developed by Martinola, Meda, Plizzari, \& Rinaldi [9]. Beschi, Meda, and Riva [10], carried out two full-scale tests confirming the efficiency of the HPFRC jacketing technique. The results indicated that the proposed technique qualified for strengthening current RC structures described by low concrete strength and low reinforcement ratios. An UHPFRC jacket can be adopted for refitting or strengthening corroded columns to ensure appropriate bearing capacity to the structures after the interference. Moreover, due to the compactness of the UHPFRC concrete matrix and the diminutive crack opening, the existing column can be protected by the jacket and therefore, the durability of the system was increased. Specially, the weak permeability of the UHPFRC can act as a fence for the breakthrough of environmental offensive agents as shown by Wanga et al. [11]. With the proposed technique it is possible to: (a) restore or enhance strength of the column, (b) progress the durability, (c) almost preserve the same geometry of the authentic structure, due to the thickness reduction of the jacket. To investigate the effectiveness of the proposed technique, ANSYS software was used to construct and analyze the nonlinear 3- D finite-element model. The verification between the constructed FE model and the experimental results carried out by Meda and Mostosi [12] was done. The behavior of $72 \mathrm{RC}$ bridge piers with degree of corrosion (40\%), compressive strength $25.0 \mathrm{MPa}$ and aspect ratio 3.25 and 6.50 subjected to seismic loads simulated by cyclic lateral displacement and axial compression force with different ratios was studied. The obtained results were compared with those measured for piers with corrosion level $40 \%$ and without strengthening and with the results of piers without corrosion ( $\mathrm{C} . \mathrm{R}=0.0$ ). The results indicated that the proposed solution was effective. Tastani and Pantazopoulou [13] developed an analytical model to describe the mechanical implications of corrosion for RC member under flexure-shear (seismic effects). A number of studies has been published, examining post repair performance for FRP jacketed corroded members, either in circumstances of exposure in continuously way or in both strength and deformation capacity recapture [14-18].

UHPFRC jacket can be adopted for strengthening or repairing corroded ridge piers to ensure adequate lateral strength to the piers after the intervention. As well as, due to the UHPFRC concrete matrix compactness and the reduction in the crack opening, the jacket can maintain the existing piers and increase the system durability. Particularly, the UHPFRC has low permeability as highlighted in Wanga et al. [11], and thus prevents the penetration of environmental aggressive agents. Utilizing migrant corrosion inhibitors in the old existing concrete restricted the possible chemical attack due to the already penetrated aggressive elements (e.g., chlorides).

Many advantages obtained by the proposed technique compared to other more traditional techniques. Actually, with the UHPFRC jacketing it is possible to (a) enhance or restore the column strength, (b) improve the durability, (c) almost maintain the same original structure geometry, due to the reduction in jacket thickness.

This study contained detailed method for improving with FRP layers and jackets. It also included an example step by step application of the suggested procedures in seismic upgrading of a R. C. column with losing in diameter of bar due to corrosion by $5 \%$.

\section{Research Significance}

This paper investigates the feasibility of strengthening corroded RC bridge piers with high levels of corrosion by using UHPFRC jacketing to enhance and restore the lateral load resistance by using FE models. Furthermore, improving a practical method to estimate the lateral load resistance of existing corroded RC bridge piers.

\section{FE Model}

ANSYS 17.0 [19], the commercial FEA software was used to execute this research.

\subsection{Assumptions}

The following assumptions were made according to the available experimental data: The corrosion over the corroded reinforcement is supposed to be uniform; an element taken into consideration bond damage under corrosion was used to simulate the bond between reinforcement bars and surrounding concrete. According to ACI 374.2R-13, cyclic lateral displacement was used to simulate seismic loads [20].

\subsection{Element Types}

As shown in Figure 1, the constructed FE model consists of four different types of elements. Concrete elements were modeled by a 3-D SOLID65 element, reinforcement bars were modeled by BEAM 188 element, the bond between reinforcement and concrete was modeled by COMBIN39 
spring element and to simulate rigid steel plate, SOLID 185 was used. The SOLID65 element is qualified for cracking in tension and crushing in compression, and behaves in a nonlinear behavior which makes it ideal for modeling concrete. The BEAM 188 element is a uniaxial compression tension element eligible to carry compression and tension.
The BEAM188 element nodes of the reinforcement bars were connected to SOLID65 element by the spring element COMBIN39 of zero length using the generalized force deflection curves, i.e. bond-slip relationship, for more details about each element see ANSYS documents [19].

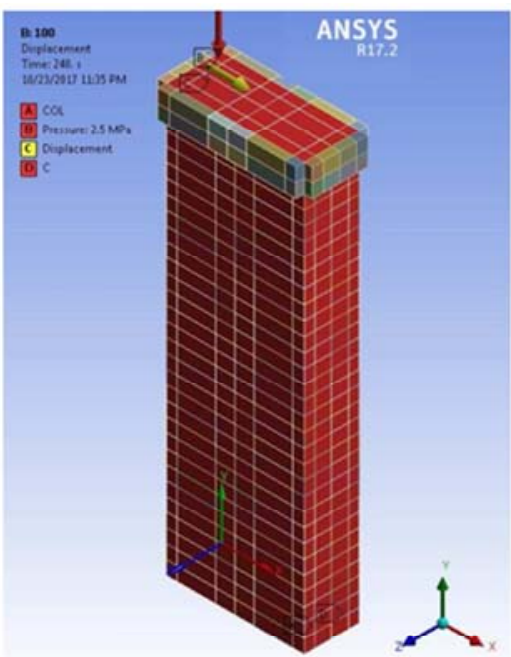

(a)

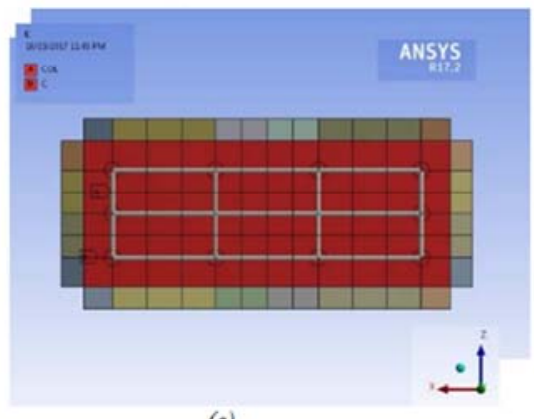

(c)
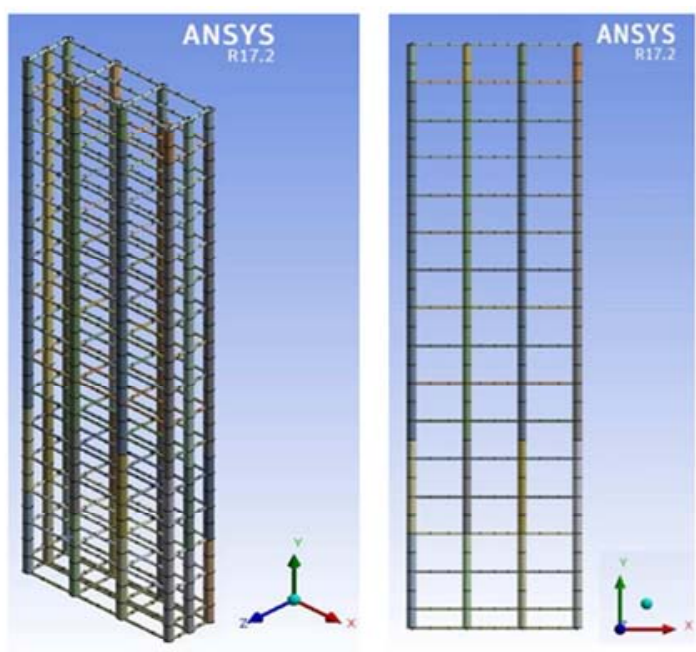

(b)

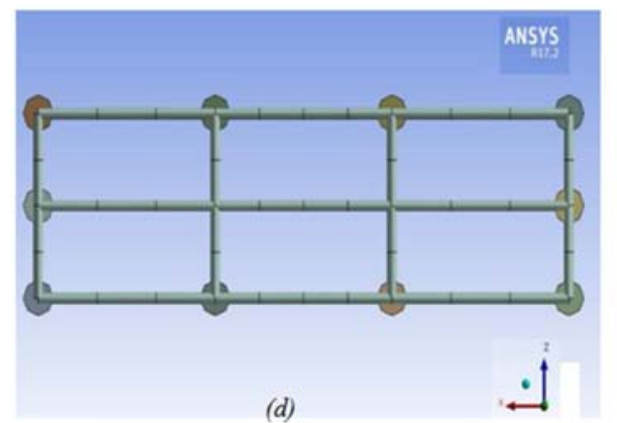

Figure 1. ANSYS model of: (a) 3-D model of the pier including concrete and top plats; (b) 3-D and elevation of longitudinal and transverse reinforcement; (c) plan of concrete, plates and steel reinforcement and (d) plan of longitudinal and transfers reinforcement.

\subsection{Material Properties and Real Constants}

\subsubsection{Modeling of Unconfined Concrete Cover}

Corrosion converts steel into rust, causing the volumetric expansion that can develop the splitting stresses in concrete. The spalling and cracking of the concrete caused by these stresses can be modeled by reducing the strength of concrete elements on this region. Equations 1-3 (Coronelli \& Gambarova, 2004) [21] were used to take corrosion effect on the compressive strength and tensile strength of unconfined concrete cover:

$$
f_{c c}^{\prime}=\frac{f_{c}^{\prime}}{1+k \frac{\varepsilon_{1}}{\varepsilon_{c o}}}
$$

On account of the cracked concrete around corroded reinforcement produced by corrosion, the concrete tensile strength should be reduced proportionally to the reduction in concrete compressive strength as following:

$$
\begin{gathered}
f^{\prime}{ }_{t c}=\frac{f_{c_{c}}^{\prime}}{f_{c}^{\prime}} f^{\prime} \\
f_{t}^{\prime}=0.62 \sqrt{f_{c}^{\prime}}
\end{gathered}
$$

Where $\mathrm{k}$; the coefficient related to the reinforcement roughness and diameter, $\varepsilon_{1}$; the smeared tensile strain. For more details about different variables and parameter in Equations 1-3 see references [21-25]. Figure 2-a shows the stress- strain curve of unconfined concrete cover with strength 25.0 $\mathrm{MPa}$ in compression of un-corroded and corroded reinforcement with level 40\% RC Pier in FE model. In ANSYS program, strain softening for concrete was considered in tension failure but was not considered in compression failure (see Figure 3).

\subsubsection{Modeling of Corroded Reinforcement}

The corrosion effect on the strength of reinforcement bars and mechanical properties was investigated experimentally 
by several researchers. Equations 4 - 6 were suggested by Du, Clark, and Chan (2005) [26] to estimate the residual crosssectional area and strength of corroded reinforcement bars. These equations depend on a retraction analyses performed on both groups of test data.

$$
\begin{gathered}
A_{S(\text { corr })}=\left(1-0.01 Q_{\text {corr }}\right) A_{S} \\
f_{y(\text { corr })}=\left(1-0.005 Q_{\text {corr }}\right) f_{y} \\
Q_{c o r r}=\left[\left(1-\left(\frac{d_{o_{c o r r}}}{d_{0}}\right)^{2}\right] 100\right.
\end{gathered}
$$

Where:

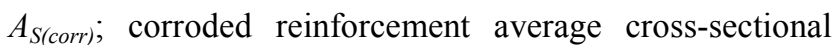
area, $A s$; non-corroded reinforcement initial cross-sectional area, $Q_{\text {corr }}$; degree of corrosion, and is calculated as the mass loss $(\%), f_{y(c o r r)}$; corroded bars yield strength, $f_{y}$; yield strength of non-corroded bars and $d_{0}, d_{\text {ocorr }}$; the un-corroded and corroded reinforcement bars diameters, respectively. Figure 2-b shows the stress strain curve of reinforcement bars in tension for un-corroded and corroded reinforcement with level 40\% RC pier in FE model.

\subsubsection{Modeling of UHPFRC}

The mechanical properties of UHPFRC depends on the percentage of mixing components, such as cement ratio, mixing water, supper plasticizer, aggregates size and steel fiber volume fraction and aspect ratio. However the theoretical equations that estimate the required properties are not enough. Therefore to get accurate properties of UHPFRC, mix design was calculated and then the required test to obtain the material properties was done. In this study, the properties of UHPFRC were those of reference (Meda \& Mostosi, 2016 [12]).

Aggregate with a maximum size of $1.3 \mathrm{~mm}$ and water/binder (cement + microsilica) ratio equal 0.17 by weight were used for UHPFRC. The concrete was reinforced with $1.2 \%$ (by volume) straight, steel micro-fibers with 15 $\mathrm{mm}$ length, $0.18 \mathrm{~mm}$ diameter and $2000 \mathrm{MPa}$ ultimate tensile strength. After 28 days of curing, the average concrete compressive strength was determined by testing cubes and was estimated by about $130 \mathrm{MPa}$. The uniaxial tensile strength was about $6 \mathrm{MPa}$. Figure 2. c shows the stress- strain curve of used UHPFRC according to Meda and Mostosi [12].

\subsubsection{Modeling of Confined Concrete Core}

As mentioned previously, the corrosion of confined reinforcement leads to the retrogression in confined concrete core properties, especially the ultimate strain and the maximum strength which can be estimated as the transverse confining reinforcement fissures. The confined concrete behavior due to corrosion can be represented by the stressstrain relationship developed by Salim and Murat [27] which can be modified and utilized in this study. The corrosion effect can be taken into consideration in the calculation by decreasing the strength and the cross-sectional area for both longitudinal and transverse reinforcement bars. Figure 2-d shows the confined concrete core stress - strain curve in compression for un-corroded and corroded reinforcement with level 40\% RC pier in FE model and Figure 2-e shows the confined concrete core stress - strain curve in tension for un-corroded and corroded with level $40 \% \mathrm{RC}$ pier in $\mathrm{FE}$ model.

\subsubsection{Model of Bond Deterioration}

(i). Corroded Reinforcement Bond Strength

Several models of bond strength damage for corroded reinforcement due to corrosion are available in previous studies [21]. The developed bond strength model by Maaddawy, Soudki, and Topper is used in the calculation process of the corroded reinforcement maximum bond strength [28] as follows:

$$
\begin{gathered}
\tau_{\text {max } c}=R\left(0.55+0.24 \frac{C_{c}}{d_{b}}\right) \sqrt{f_{c}^{\prime}}+0.191 \frac{A_{v}+f_{y h}}{S d_{b}}(7) \\
R=\left(A_{1}+A_{2} X_{\text {corr }}\right)
\end{gathered}
$$

where $R$ is a factor that is taken in consideration the bond strength reduction, $A_{1}$ and $A_{2}$ are coefficients which reflect the corrosion rate of an accelerated corrosion process. These coefficients values were estimated by $A_{1}=1.104, A_{2}=-0.024$, for $0.09 \mu \mathrm{A} / \mathrm{cm}^{2}$ corrosion process. $X$ is the rate of corrosion, and is stated as the percentage of rebar mass loss. For more details see (Maaddawy, Soudki, \& Topper, 2005 [28]).

(ii). Model of Modified Local Bond Stress-slip

The effect of corrosion on the local bond behavior is taken into consideration by using and modifying the developed bond stress-slip model in the Design of concrete structures: CEB-FIP, 1990 [29] as:

$$
\begin{gathered}
\tau=\tau_{\max c}\left(\frac{S}{S_{1}}\right) \alpha 0 \leq \mathrm{S} \leq \mathrm{S}_{1} \\
\tau=\tau_{\operatorname{maxc}} \mathrm{S}_{1} \leq \mathrm{S} \leq \mathrm{S}_{2} \\
\tau=\tau_{\max c}-\left(\tau_{\max c}-\tau_{f}\right)\left(\frac{S-S_{2}}{S_{3}-S_{2}}\right) \mathrm{S}_{2} \leq \mathrm{S} \leq \mathrm{S}_{3}(9) \\
\tau=\tau_{\mathrm{f}} \mathrm{S}_{3}<\mathrm{S}
\end{gathered}
$$

With the generally designed, it is noticeable that concrete cover thickness and the amount of transverse reinforcement, the failure bond in corroded reinforcement is usually a result of splitting [21]. Subsequently, the parameters values of the modified bond stress-slip model can be selected as: $\alpha=0.40$; $\mathrm{S}_{1}=0.6 \mathrm{~mm} ; \mathrm{S}_{2}=0.6 \mathrm{~mm} ; \mathrm{S}_{3}=2.50 \mathrm{~mm} ; \tau_{\mathrm{f}}=0.15 \tau_{\text {maxc }}$. Figure 2-f shows an example of the modified bond model for uncorroded and corroded reinforcing bars.

\subsection{Material Properties and Real Constants}

To reduce concentration of stresses at the locations of applied loads, steel plate elements (Solid185) are used to model rigid steel plates. Poisson's ratio equals 0.3 and a very high modulus of elasticity are used. 


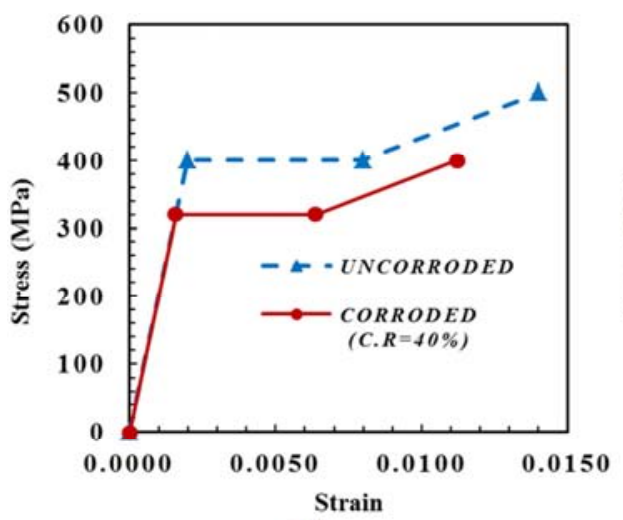

(a)

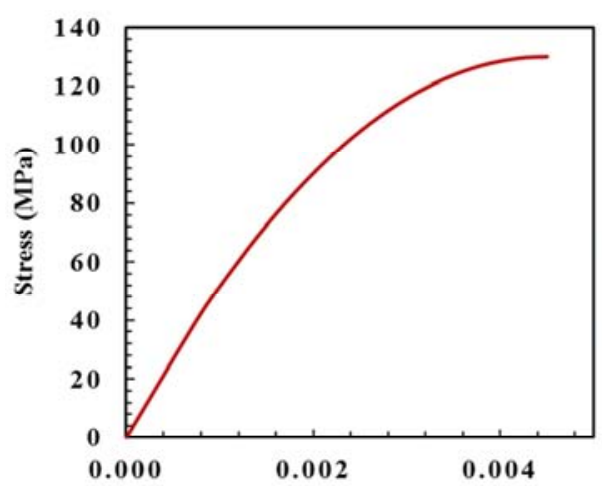

Strain

(c)

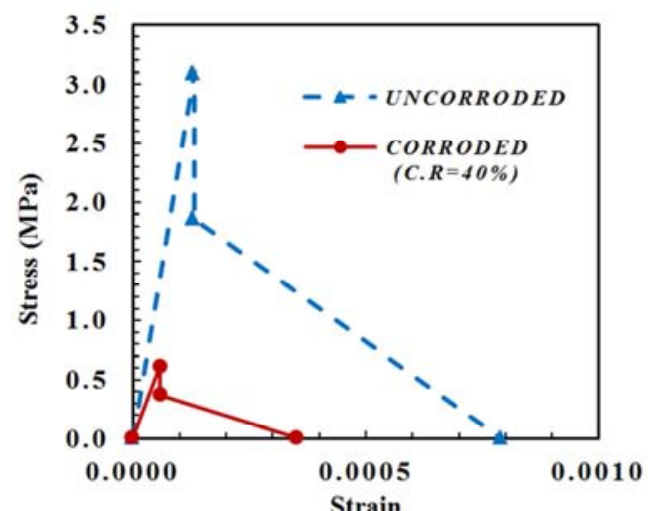

(e)

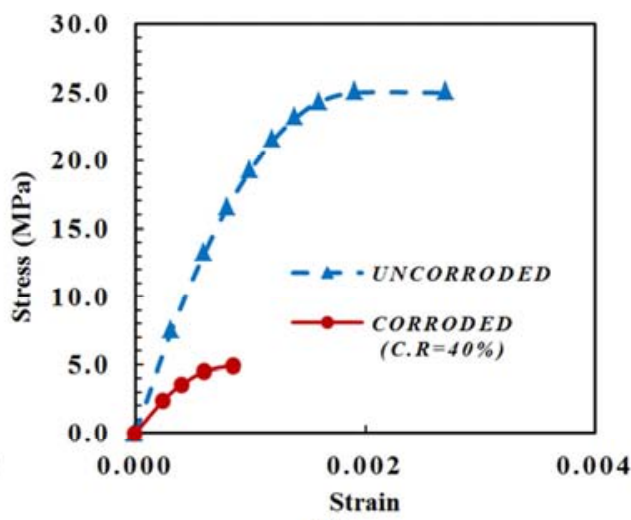

(b)

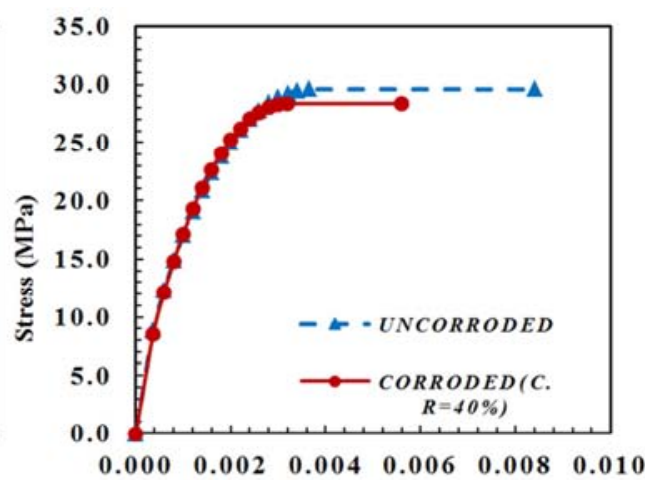

Strain

(d)

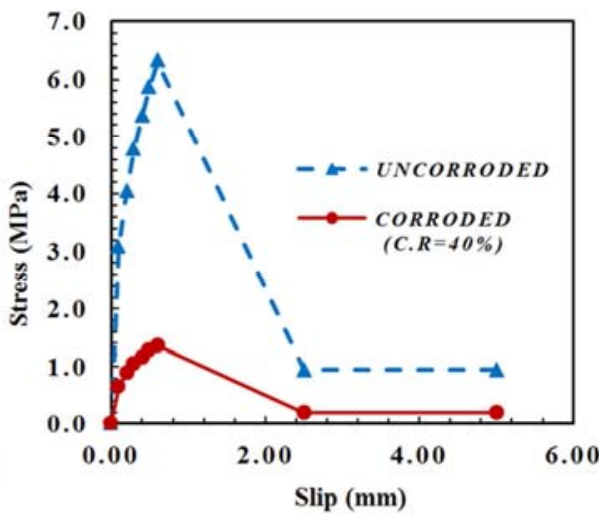

(f)

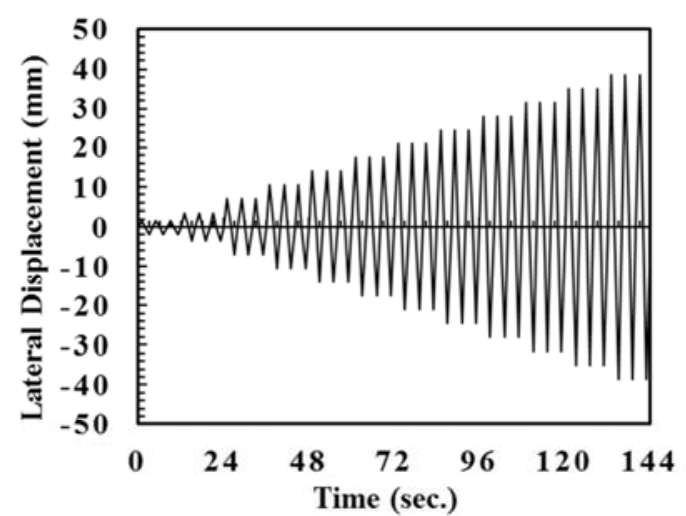

(g)

Figure 2. Pier FE model: (a) Steel reinforcement in tension; (b) Concrete cover in compression; (c) UHPFRC;(d) Concrete core in compression; (e) Confined concrete core in tension; (f) Bond slip model and ( $g$ ) Lateral cyclic displacement. 


\subsection{Boundary Conditions and Loading}

In this study, all columns are modeled as cantilevers (single or double) as well as the experimental columns of reference [12] have fixed bases. Therefore, all degrees of freedom at all base elevation nodes are restricted. The combination between constant axial load and cyclic lateral load is taken into consideration to test all the columns. The first stage of analysis is stratifying axial load to the rigid plate at top of the column. Followed by applying cyclic lateral load in the next stage; where lateral displacement is applied at side of the rigid plate in $\mathrm{x}$ - direction. ACI 374.2R$13,[20]$ cyclic loading history is utilized and shown in Figure 2-g. The amplitudes of twice repeated lateral displacement cycles were $0.5 \Delta y, 1.0 \Delta y, 2.0 \Delta y, 3.0 \Delta y, 4.0 \Delta y, 5.0 \Delta y$, etc. up to failure, where $\Delta y$ is the displacement at yielding by assuming effective stiffness of columns [30].

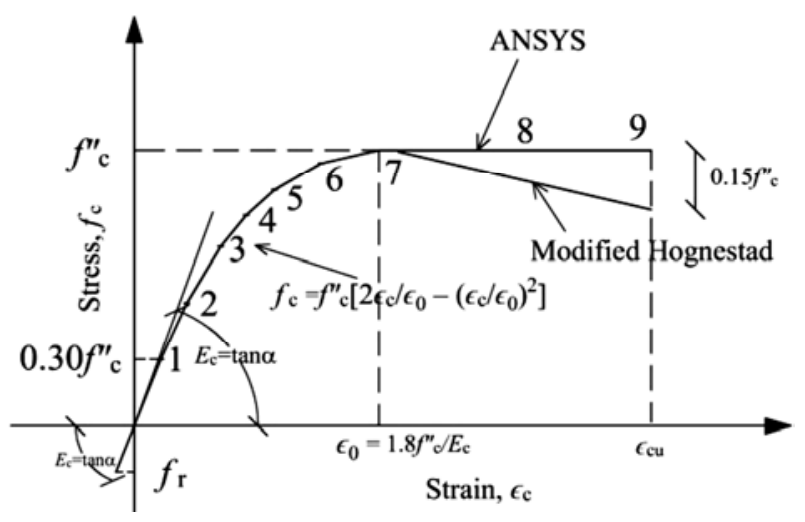

(a)

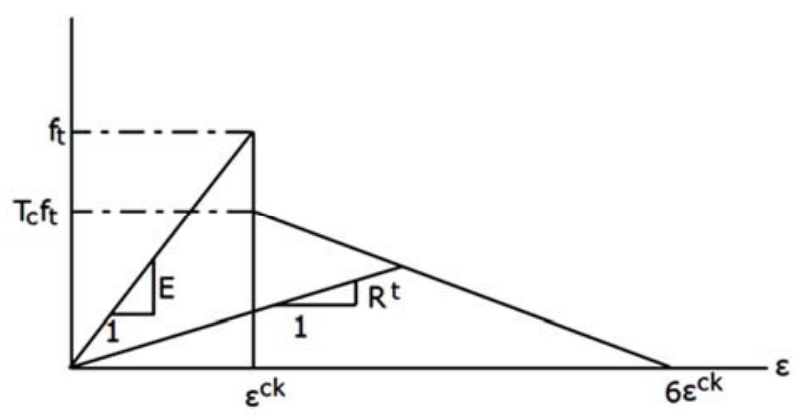

(b)

Figure 3. Stress-strain diagrams for concrete: (a) modified Hognestad for un-confined and typical for ANSYS and (b) tension model in ANSYS.

\section{Validation of Finite Element Model}

The experimental studies [31-34] are chosen to make the simulation of seismic loads for studying the behavior of corroded RC columns to approve the fineness of the suggested FE model. Meda et al. [31] studied four RC columns, two of them are corroded in accelerated process. After that, the reinforcement bars are removed from RC columns and tested in tension to investigate the effect of corrosion on the stress- strain relationship. The third column is corroded to about $20 \%$ of the required corrosion then subjected to cyclic loads. Finally, the last column is utilized as a reference of un corroded specimen. Li et al., [32], carried out an experimental study included fourteen RC columns with the same specifications, which are exposed to axial force with different ratios from 0.13 to 0.35 and different corrosion levels. Transverse as well as longitudinal reinforcement bars are corroded up to the prospective levels of corrosion from 0 to $19.17 \%$ in terms of mass loss and the effect of retrofitting system on corroded RC columns using both steel and CFRP jackets. Another experimental investigation by Wang [33] contained seventeen RC columns with the same specifications, which are exposed to axial force with different ratios from 0 to 0.5 and different corrosion levels. Transverse as well as longitudinal reinforcement bars are corroded up to the prospective levels of corrosion from 0 to $25 \%$ in terms of mass loss. Generally, the data from experimental study of seven RC columns are chosen to validate the suggested FE model, in which both corroded and un-corroded RC columns and also different corrosion levels are tested. In the fourth experimental study carried out by Goksu [34], thirteen RC columns are exposed to corrosion in acceleration process in which the level of corrosion differs from 0 to $54 \%$, subsequently tested under axial force as singer curvature with constant ratio of 0.18 along with cyclic loading.

The details of RC column specimens by previous experiments are shown in Figure 4, and the material properties used in the FE analysis are listed in Table 1. The maximum lateral load determined from hysteresis loops of both specimens tested experimentally by previous researchers and those analyzed by current FEA. The comparison between the maximum lateral loads by the previous experimental studies and those from FE analysis are shown in Figure 5. Figure 6 shows the FE backbone curves for both corroded and un-corroded RC piers in these four experimental studies. Also, Figure 7-a represents the hysteresis loops of strengthened specimen tested by Meda et al. [12], Figure 7-b shows the backbone curve for Meda's specimen analyzed by FE model and Figure 7-c represents the hysteresis loops of the specimen $\left(\mathrm{C}_{2}\right.$ column $)$ tested by Gong's [32]. From these figures one can be observed that there was a good agreement between FE results and the previous experimental studies in terms of the maximum lateral load resistance, initial stiffness, and maximum displacement. A previous study has done using the numerical FE model and the corrosion levels $0 \%$ (uncorroded), 10\%, 20\%, and 40\% were taken into account [35]. Based on this previous study, the higher corrosion results in the lower lateral load resistance, and its significant reduction can be seen when the RC piers were highly corroded, which is the corrosion level $40 \%$. With high corrosion level (C. $\mathrm{R}=40 \%$ ), the width of the crack in the concrete cover increases. Therefore, the concrete cover of the section is spalling off and there is a significant decrease in the concrete cross-sectional area of the pier, while the concrete cover has almost $30 \%$ area of the whole section. 
Therefore, the compressive strength of the corroded pier decreases significantly. Therefore, the proposed technique will be applied to RC pier with corrosion level (C. R) $=40 \%$. In order to investigate the proposed technique, the concrete cover of the corroded piers with corrosion level $40 \%$ was replaced with $40 \mathrm{~mm}$ UHPFRC jacketing. In case of serious corrosion happens on steel bars, some additional reinforcement should be a supplement but, traditional jacketing presents some inconvenience, as the jacket thickness has governed by the steel cover (both external and internal), and then it is, often, higher than 70-100 mm, Fib Bulletin 24, [8]. As a consequence, the increase of the section geometry is not negligible, leading to an increase in both mass and stiffness, which can give some problems concerning the seismic behavior. As a consequence, the use of a thin HPFRC layer $(30-40 \mathrm{~mm})$ avoided the traditional steel reinforcement in the jacket. After strengthening of corroded RC bridge piers with corrosion level $40.0 \%$, with replacing cracked or spalling concrete cover with $40 \mathrm{~mm}$ UHPFRC jacket in thickness, the UHPFRC jacket increases the confinement of core concrete, support reinforcing bars and decreases the probability of local buckling of compression bars. Therefore, the lateral load resistance of corroded piers increases with strengthening to exceed the lateral load resistance of un-corroded piers with ratio according to different structural parameters. There is a typical secondary loading problem in the behavior of the structure after repair as removing 1.5 live loads which were $60 \%$ before repairing and $90 \%$ after repairing. But this is in case of using traditional jacketing, as mentioned above, where the jacket thickness is often higher than 70-100 mm. While the thin layer of HPFRC is within $30-40 \mathrm{~mm}$.

\section{Parametric Investigation}

\subsection{Numerical Models of Corroded RC Piers}

The suggested 3D non-linear FE model discussed above, to investigate the different parameters effect on the behavior of corroded RC bridge piers under seismic, and to evaluate their lateral load resistance reduction, numerical simulations were carried out. Table 2 summarized the range of parametric study. Figure 8 represents general details of study specimen. Figure 9 shows the crack patterns after applying a lateral load, flexural cracks start to occur at the pier tension side at the plastic hinge zone. The greater the lateral load, the higher cracks progress in-depth and develop more in the height of the pier, which leads to making the compression zone smaller and smaller, and finally crushing of concrete in compression occurs. Figure 10 shows Load-displacement hysteretic curve of RC pier for corroded pier from FEA and Figure 11 shows the corroded RC piers backbone curve with aspect ratio 3.25, compressive strength $25.0 \mathrm{MPa}$ and longitudinal reinforcement ratio $1.13 \%$. Where, this study focus on the lateral load resistance of corroded RC bridge piers, but the behavior of different structural parameters on the ductility of corroded RC bridge piers must be studied.

\subsection{Numerical Results of Corroded RC Piers}

Tables 3 and 4 demonstrate a summary of results for studied RC bridge piers with aspect ratio 3.25 and 6.50 and compressive strength $25 \mathrm{MPa}$.

\subsubsection{Effect of Corrosion Level}

The effect of corrosion level on the lateral load resistance for $\mathrm{RC}$ bridge piers with aspect ratio 3.25 and 6.50 and compressive strength $25 \mathrm{MPa}$ was shown in Table 3 and in Figure 12 for aspect ratio 3.25 by dividing the values of $V_{p}$ corroded to the values of $\mathrm{V}_{\mathrm{p} \text { uncorroded }}\left(\mathrm{V}_{\text {pcorr }} / \mathrm{V}_{\text {pun }}\right)$. As observed, from the analysis of results, the lateral load resistance was decreased by increasing corrosion level from 0.0 to $40 \%$ and was increased by strengthening of piers with corrosion level $40.0 \%$ by replacing concrete cover by UHPFRC jacket with $40.0 \mathrm{~mm}$ thickness. For example in the pier with an axial force ratio $10 \%$, aspect ratio 3.25 and longitudinal reinforcement $2.01 \%$, when the corrosion level was increased from $0 \%$ to $40 \%$ and $40.0 \%$ with strengthening (i.e. 40 STR), the lateral load resistance was reduced by $50.4 \%$ and was increased by $73.20 \%$ respectively, and mode of failure was changed from flexure failure to local buckling and flexure shear failure respectively.

For the same pier but with aspect ratio 6.50 , when the level of corrosion was increased from $0 \%$ to $40 \%$ and $40.0 \%$ with strengthening, the lateral load resistance was reduced by $44.10 \%$ and was increased by $70.0 \%$ respectively, and mode of failure was changed from flexure failure to flexure shear and flexure failure respectively. With a low longitudinal reinforcement ratio $(1.13 \%)$, the percentage of lateral load resistance of strengthening corroded pier was increased with increasing of axial force ratio for piers with aspect ratio 3.25 and 6.50. As the mode of failure is local buckling for piers with axial force ratio 10, 20, and 30\% and the ratio of increasing in lateral load resistance for un-corroded piers was less than this ratio for strengthening corroded piers. For example, in the pier with aspect ratio 3.25 , longitudinal reinforcement $1.13 \%$, and the axial force ratio $=10 \%, 20 \%$ and $30 \%$, when corrosion level was increased from $0 \%$ to $40 \%$ STR, the lateral load resistance was increased by 40.0, 44.10, and $75.50 \%$, respectively. For the same pier but with aspect ratio 6.50 , the lateral load resistance was increased by $30.50,45.90$, and $74.20 \%$ respectively. Otherwise, for piers with a high longitudinal reinforcement ratio $(4.90 \%)$ and aspect ratio 3.25 , the percentage of lateral load resistance of strengthening corroded pier was decreased with increasing of axial force. As the buckling load of compression bars control the lateral load of strengthening corroded piers with high axial force ratio, therefore the lateral load resistance of strengthening corroded piers was decreased by increasing of the axial force ratio. For example, in the pier with aspect ratio 3.25 , longitudinal reinforcement $4.90 \%$, and the axial force ratio $=10 \%, 20 \%$ and $30 \%$, when corrosion level was increased from $0 \%$ to $40 \%$ STR, the lateral load resistance was increased by $38.20,29.60$, and $8.80 \%$ respectively.

From Table 3 and Figure 12 it was noted that, the percentage of increase in lateral load resistance of strengthening corroded pier with aspect ratio 6.5 is smaller than that pier with aspect ratio 3.25 , especially with low 
longitudinal reinforcement ratio (1.13 and $2.01 \%)$ and low
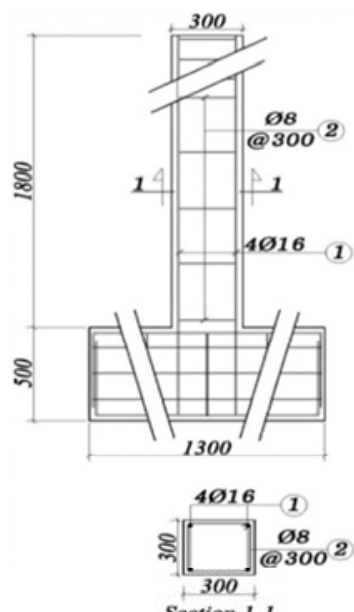

(a)

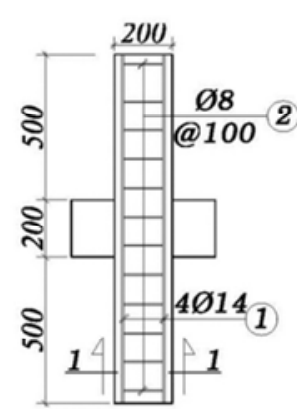

40141

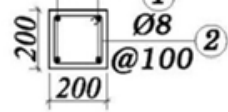

Section 1-1

(b)

axial force ratio (10.0 and $20.0 \%$ ).

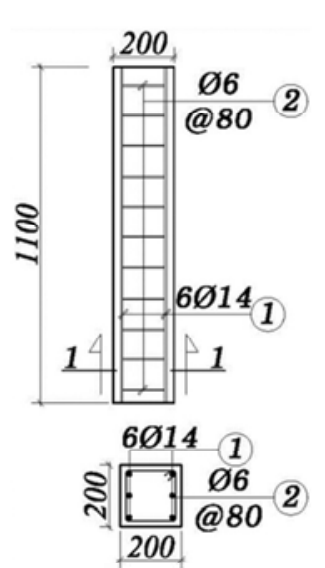

Section 1-1

(c)

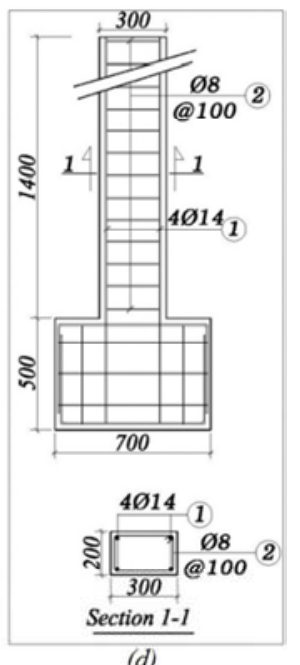

(d)

Figure 4. The details of RC column specimens by previous experiments: (a) Meda et al., 2014 [31]; (b) Li et al., 2009 [32]; (c) Wang, 2003 [33] and (d) Goksu, 2012 [34].

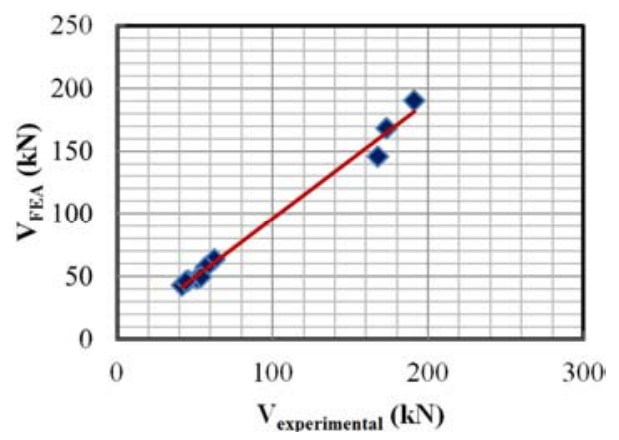

Figure 5. Comparison between the maximum lateral loads from the previous experimental studies and those from FE analysis.

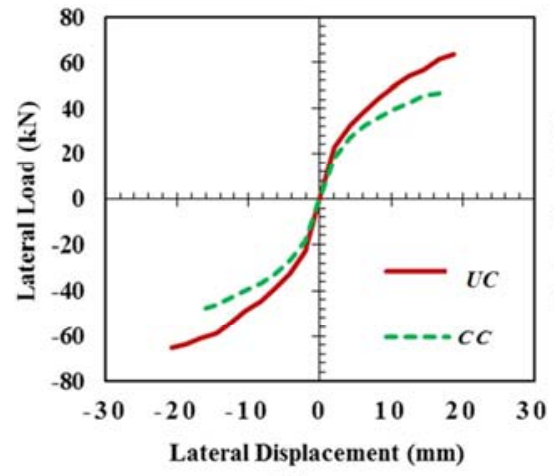

(a)

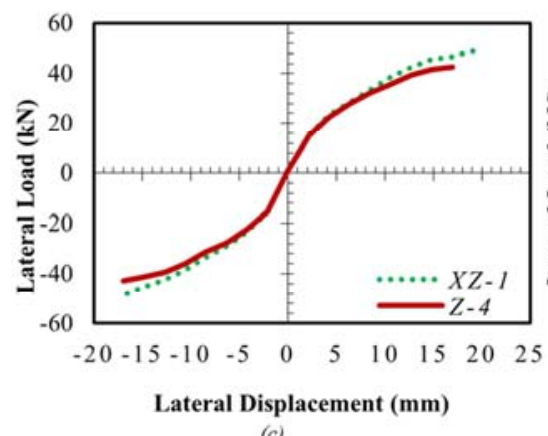

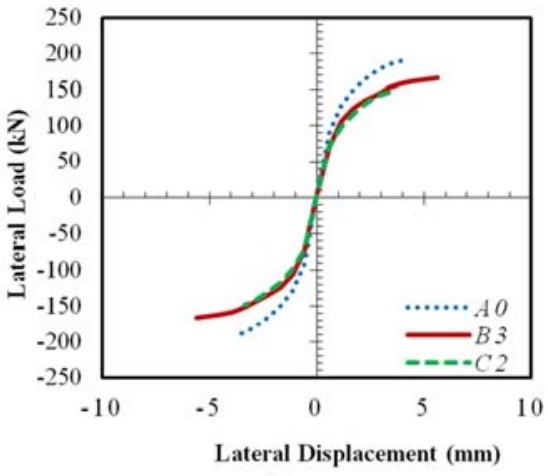

(b)

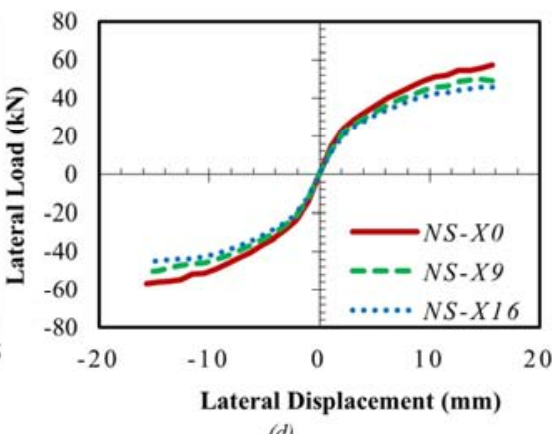

(d)

Figure 6. The FE backbone curve of specimens tested by (a) Meda et al., 2014 [31]; (b) Li et al., 2009 [32]. (c) Wang, 2003 [33] and (d) Goksu, 2012 [34]. 


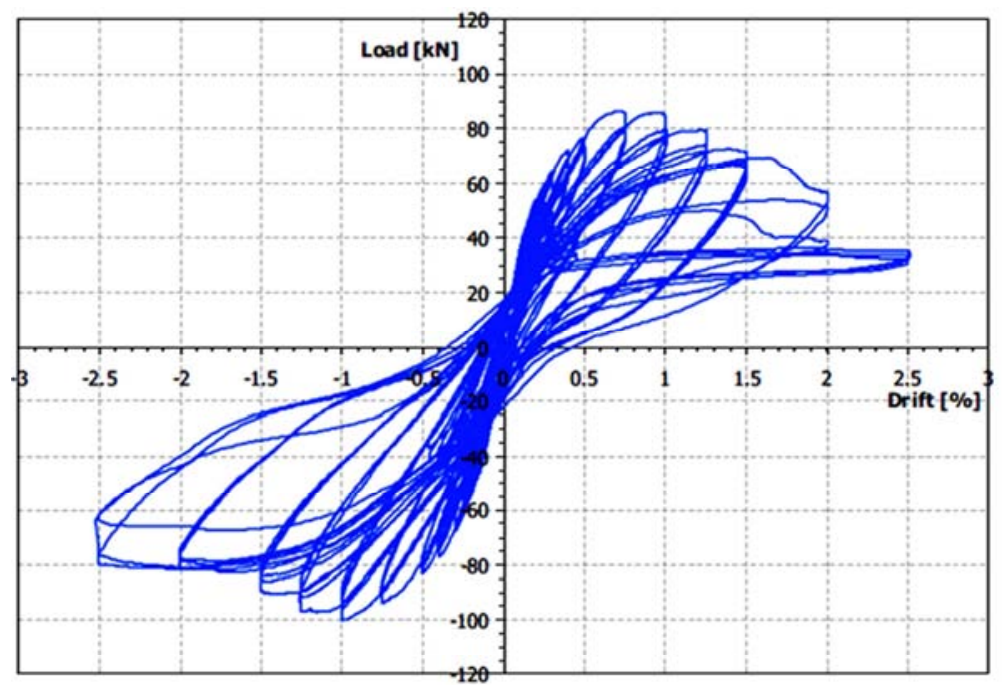

(a)

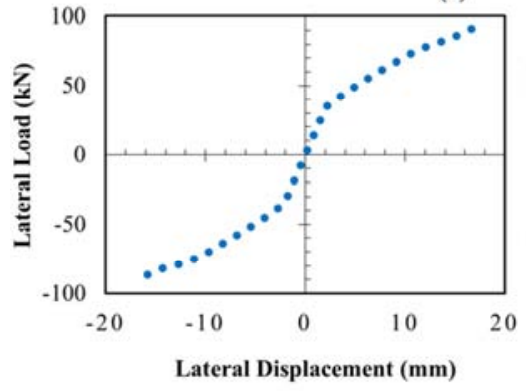

(b)

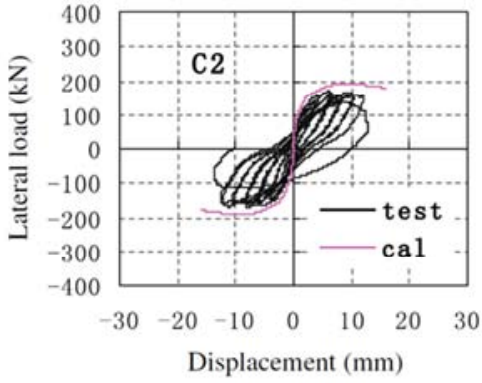

(c)

Figure 7. (a) Hysteresis loops of strengthened specimen tested by Meda et al., 2016 [12]; (b) The backbone curve of specimen analyzed by FE model., (c) The hysteresis loops of specimen ( $C_{2}$ column) tested by Gong's, 2009 [32].

Table 1. Material properties of RC column specimens by previous experiments used in FE analysis.

\begin{tabular}{|c|c|c|c|c|c|c|c|}
\hline \multirow{2}{*}{ Specimens } & \multicolumn{2}{|c|}{ Un-confined Concrete Cover } & \multicolumn{2}{|c|}{ Confined Concrete Core } & \multirow{2}{*}{$\begin{array}{l}\text { Longitudinal } \\
\text { RFT. } \\
\text { f }_{\mathbf{y}}(\mathrm{MPa})\end{array}$} & \multirow{2}{*}{$\begin{array}{l}\text { Transverse } \\
\text { RFT. } \\
\text { f }_{\mathrm{yt}}(\mathrm{MPa}) \\
\end{array}$} & \multirow{2}{*}{$\begin{array}{l}\text { Max. Bond } \\
\max (\mathrm{MPa})\end{array}$} \\
\hline & $f_{c}^{\prime}$ (MPa) & $f_{t}^{\prime}$ (MPa) & $f_{c}^{\prime}$ (MPa) & $f_{t}^{\prime}$ (MPa) & & & \\
\hline UC (Meda et al., 2014) [31] & 20 & 2.8 & 21.8 & 2.90 & 520 & 520 & 5.2 \\
\hline CC (Meda et al., 2014) [31] & 10.6 & 1.5 & 21.6 & 2.9 & 468 & 520 & 2.8 \\
\hline A0 (Li et al., 2009) [32] & 44.80 & 4.2 & 48.7 & 4.3 & 385 & 327 & 9.4 \\
\hline B3 (Li et al., 2009) [32] & 22.8 & 2.1 & 48.2 & 4.3 & 352 & 299 & 5.6 \\
\hline C2 (Li et al., 2009) [32] & 27.1 & 2.5 & 48.4 & 4.3 & 363 & 308 & 6.7 \\
\hline XZ-1 (Wang, 2003) [33] & 24.6 & 3.1 & 28.2 & 3.3 & 415 & 325 & 6.4 \\
\hline Z-4 (Wang, 2003) [33] & 9.60 & 1.2 & 27.7 & 3.3 & 378 & 296 & 3.4 \\
\hline NS-X0 (Goksu, 2012) [34] & 25.5 & 3.13 & 29.89 & 3.39 & 460 & 486 & 8.27 \\
\hline NS-X9 (Goksu, 2012) [34] & 18.51 & 2.23 & 29.63 & 3.38 & 439 & 486 & 6.82 \\
\hline NS-X16 (Goksu, 2012) [34] & 14.71 & 1.81 & 29.43 & 3.36 & 423 & 486 & 5.62 \\
\hline
\end{tabular}

Table 2. The range of parametric study.

\begin{tabular}{|c|c|c|c|}
\hline No. & Parameters & Notation & Range of study \\
\hline 1 & Corrosion level & C. R $(\%)$ & $0.0,40.0$ and $40.0 \mathrm{STR}^{*}$ \\
\hline 2 & Compressive strength of concrete (MPa) & $f_{c}^{\prime}$ & 25 \\
\hline 3 & Axial force ratio (N. R) & $\mathrm{N} /\left(\mathrm{f}_{\mathrm{c}} \cdot \mathrm{Ag}\right)(\%)$ & 10,20 and 30 \\
\hline 4 & Longitudinal reinforcement ratio $\left(\rho_{t}\right)$ & As/(b. h) (\%) & $1.13(10 \varnothing 12) ; 2.01$ (10Ø16); 3.14 (10Ø20) and 4.90 (10Ø25) \\
\hline 5 & $\begin{array}{l}\text { Longitudinal reinforcement strength } \\
(\mathrm{MPa})\end{array}$ & $\mathrm{F}_{\mathrm{y}} / \mathrm{f}_{\mathrm{u}}$ & $400 / 600$ \\
\hline 6 & Transverse reinforcement ratio $\left(\rho_{v}\right)$ & $\mathrm{A}_{v} /(\mathrm{b} . \mathrm{s})(\%)$ & $\begin{array}{l}\text { Group (1) } 0.17 \text { (Ø8@ @300) with } 2 \text { branches); } \\
\text { Group (2) } 0.25 \text { (Ø8@200 with } 2 \text { branches); Group (3) } 0.75 \text { (Ø8 @100 with } 3 \text { branches). }\end{array}$ \\
\hline 7 & Transverse reinforcement strength (MPa) & $\mathrm{F}_{\mathrm{y}} / \mathrm{f}_{\mathrm{u}}$ & r \\
\hline 8 & Cross section $(\mathrm{mm})$ & $b * h * L$ & $200 * 500 *(1500$ OR 3000$)$ \\
\hline 9 & Aspect ratio & $(\mathrm{L} / \mathrm{d})$ & $3.25,6.50$ \\
\hline
\end{tabular}

* 40 STR means the corrosion level $=40 \%$ with strengthening. 

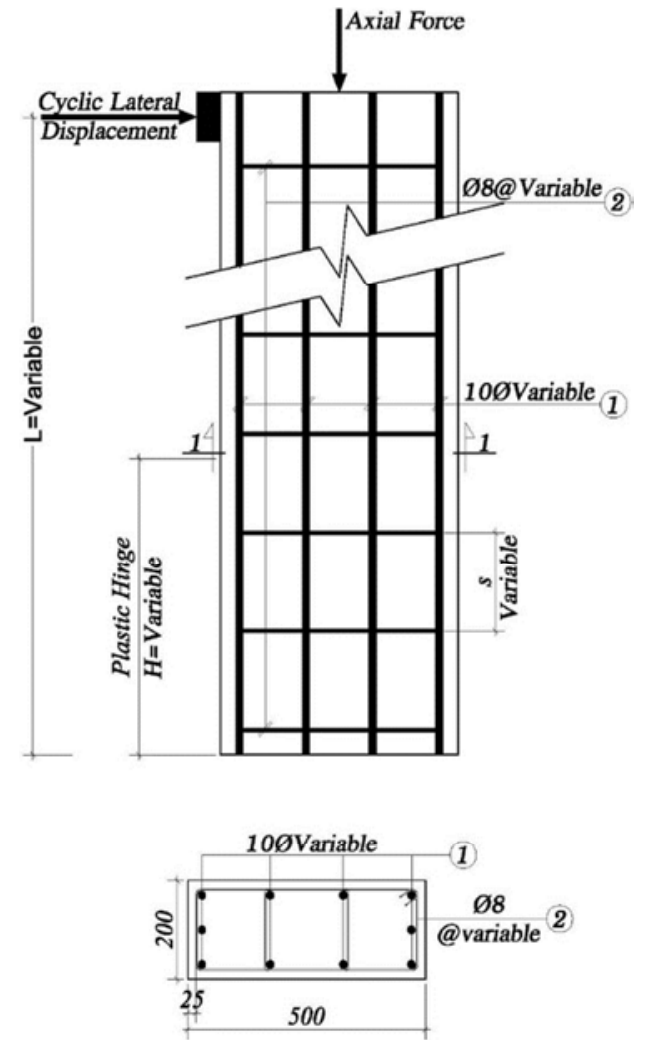

Section 1-1

Figure 8. General details of study specimen
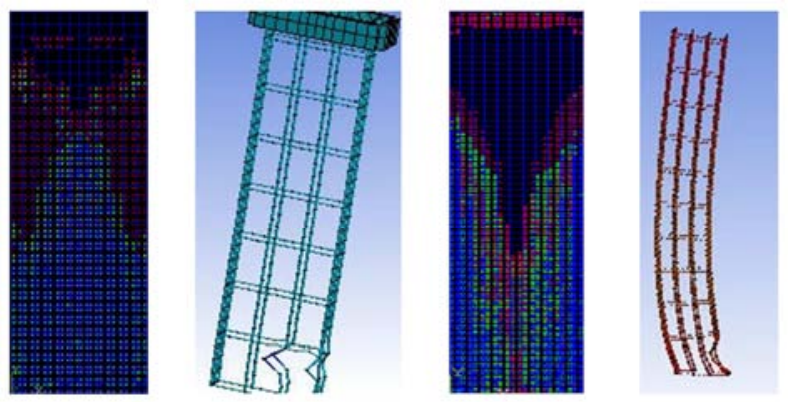

(a)

(b)

Figure 9. Crack pattern and failure modes for piers with; (a) Aspect ratio 3.25 and (b) Aspect ratio 6.50 .

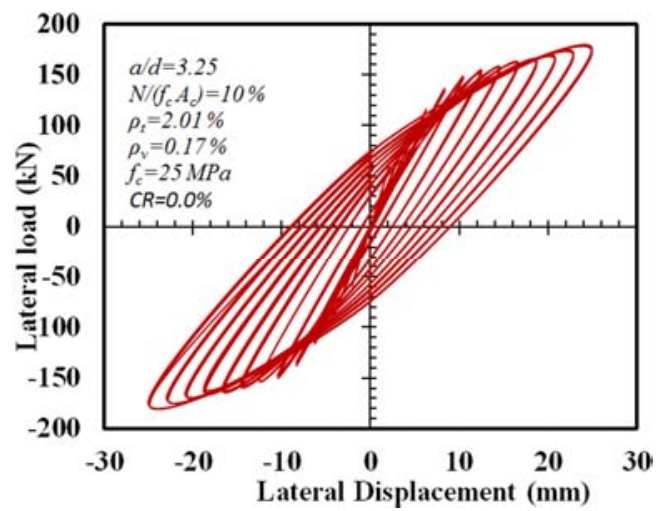

Figure 10. Load-displacement hysteretic curves of RC piers.

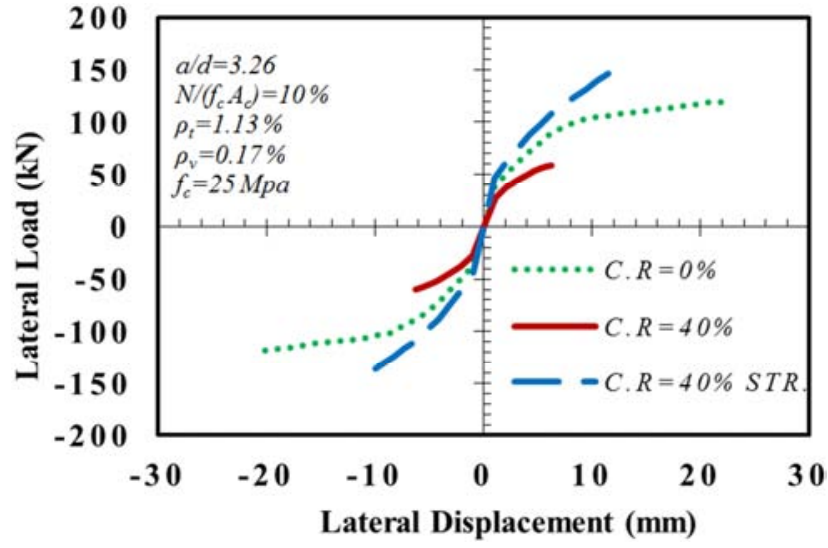

Figure 11. The backbone curve of corroded RC piers with aspect ratio 3.25, $f_{c}=25.0 \mathrm{MPa}$ and $\rho_{t}=1.13 \%$.

\subsubsection{Effect of Axial Force Ratio}

The effect of axial force ratio on lateral loads for piers with aspect ratio 3.25 and 6.50 and compressive strength $25 \mathrm{MPa}$ are shown Figure 13 and listed in Table 3 by dividing the values of lateral loads at different axial force ratio to that at $10 \%$ axial force ratio $\left(V_{p} / V_{p}(\mathrm{~N} . R 10 \%)\right.$. In this study, three values of axial force ratio were taken into account (i.e. $10 \%$, $20 \%$ and $30 \%$ ). It was observed that the lateral load resistance of strengthening corroded piers was increased by increasing of axial force ratio especially, with a low longitudinal reinforcement ratio. For example, in the strengthening corroded piers with aspect ratio 3.25, longitudinal reinforcement ratio $1.13 \%$ and corrosion level $40 \%$ with strengthening, the lateral load resistance was increased by $29.0 \%$ and $62 \%$ approximately as the axial force was increased from 10 to $20 \%$ and from 10 to $30 \%$, respectively. For the same pier but with aspect ratio 6.50 , the lateral load resistance was increased by $38.60 \%$ and $65.30 \%$ approximately.

For strengthening corroded piers with longitudinal reinforcement ratio of 2.01 and $3.14 \%$, the lateral load resistance was decreased by increasing axial force ratio from 10 to $20 \%$, and then was increased by increasing axial force ratio from 20.0 to $30.0 \%$. However, for strengthening corroded piers with longitudinal reinforcement ratio $4.90 \%$, the lateral load resistance was increased by increasing axial force ratio from 10.0 to $20.0 \%$, and then was decreased by increasing axial force ratio from 20.0 to $30.0 \%$. It is noted that the lateral load resistance of strengthening corroded piers was increased by increasing of axial force ratio for piers with aspect ratio 6.50 more than that for piers with aspect ratio 3.25 .

\subsubsection{Effect of Longitudinal Reinforcement Ratio}

The effect of longitudinal reinforcement ratio on the lateral load resistance of strengthening corroded piers with aspect ratio 3.25 and 6.50 and compressive strength $25 \mathrm{MPa}$ are listed in Table 3 by dividing the values of lateral loads at different longitudinal reinforcement ratio to that at $1.13 \%$ longitudinal reinforcement ratio $\left(V_{p} / V_{p(\rho t 1.13 \%)}\right)$ and drawn in Figure 14 only for aspect ratio 3.25 . It was observed that, the 
lateral load resistance of strengthening corroded piers was increased by an increase in longitudinal reinforcement ratio, especially with low axial force ratio $(10.0 \%)$ and with aspect ratio 6.50 . For example, strengthening corroded piers with axial force ratio $10 \%$ and aspect ratio 6.50 , the percentage of increase in lateral load resistance was estimated by approximately $95.5,134.5$, and $203.9 \%$ when longitudinal reinforcement ratio was increased from 1.13 to $2.01,3.14$, and $4.90 \%$. For the same piers but with aspect ratio 3.25 , an approximately $80.6,122.1$, and $143.1 \%$ increase of the percentage of lateral load resistance when longitudinal reinforcement ratio was increased from 1.13 to $2.01,3.14$, and $4.90 \%$.

It was noted from Table 3 that the effect of longitudinal reinforcement ratio on the increase of the percentage of lateral load resistance of strengthening corroded piers was decreased with the increase of axial force ratio. It was also observed that, the effect of longitudinal reinforcement ratio on the increase of the percentage of lateral load resistance of strengthening corroded piers with aspect ratio 6.50 was greater than that for piers with aspect ratio 3.25.

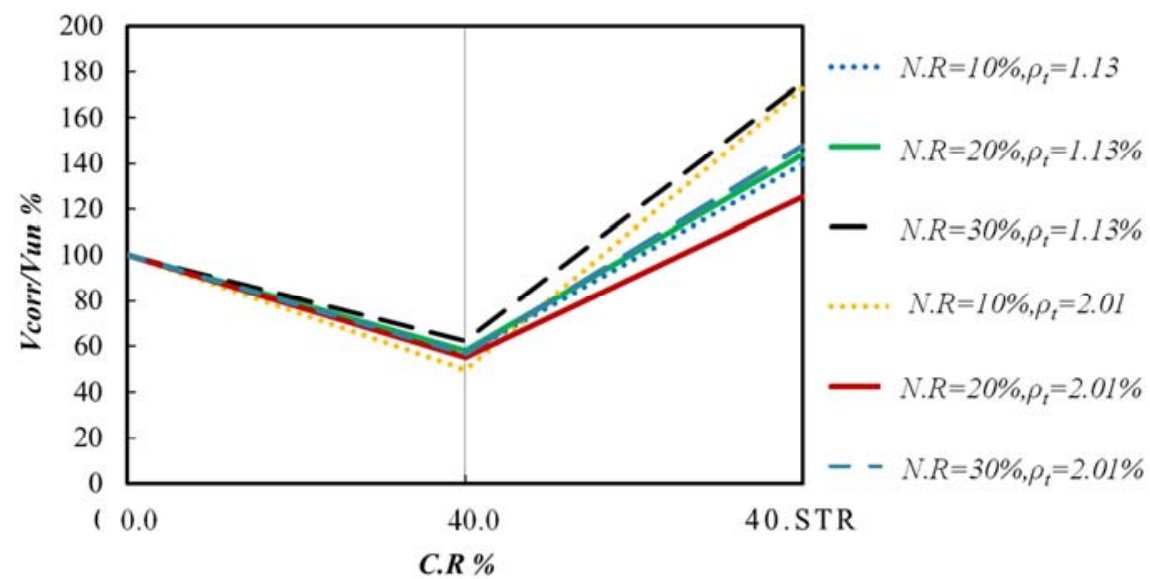

Figure 12. Effect of corrosion level on lateral load resistance of RC piers with aspect ratio 3.25, compressive strength 25.0 MPa and longitudinal steel ratio $\rho_{t}=1.13$ and $2.01 \%$.

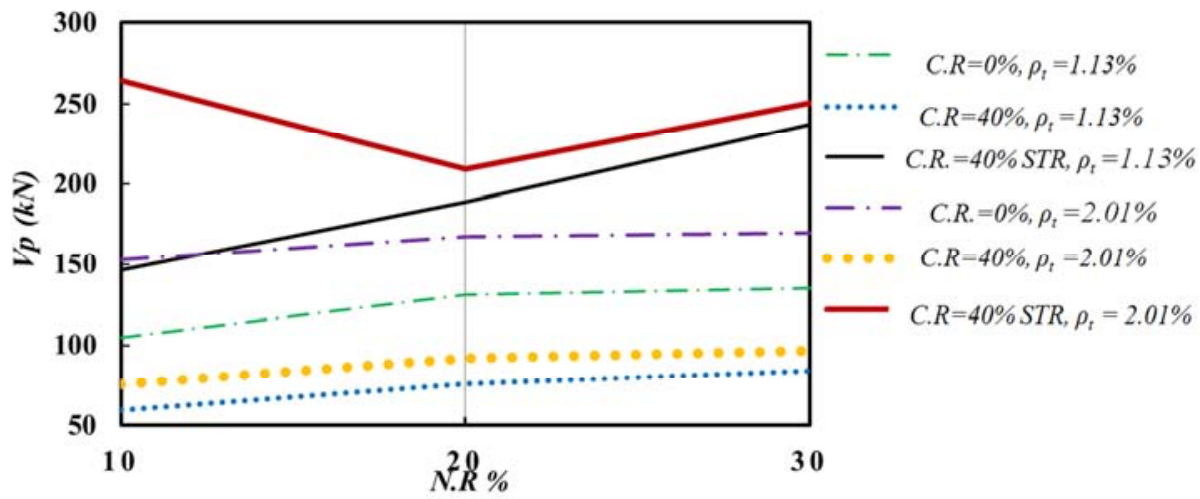

Figure 13. Effect of axial force ratio on lateral load of $R C$ piers with aspect ratio 3.25, compressive strength 25.0 MPa and longitudinal steel ratio $\rho_{t}=1.13$ and $2.01 \%$.

Table 3. Effect of corrosion level, axial force ratio and longitudinal steel ratio on lateral loads for piers with aspect ratio 3.25 and 6.50 and compressive strength $25 \mathrm{MPa}$.

\begin{tabular}{|c|c|c|c|c|c|c|c|c|c|c|c|c|c|c|}
\hline \multirow[b]{2}{*}{$\mathbf{f}_{\mathbf{c}}, \mathbf{a} / \mathbf{d}$} & \multirow[b]{2}{*}{$\rho_{\mathrm{t} \%}$} & \multirow[b]{2}{*}{ N. R\% } & \multirow[b]{2}{*}{ C. $\mathbf{R} \%$} & \multicolumn{3}{|c|}{ Lateral Load $\left(V_{p}\right)(k N)$} & \multicolumn{2}{|c|}{$\left(V_{\text {pcorr }} / V_{\text {pun }}\right) \times 100$} & \multicolumn{3}{|c|}{$V p / V p_{(\mathrm{N} . \mathrm{R} 10 \%)} \times 100$} & \multicolumn{3}{|c|}{$V p / V p_{(\rho t 1.13 \%)} x 100$} \\
\hline & & & & 0.0 & 40.0 & 40.0 STR. & 40.0 & 40.0 STR. & 0.0 & 40.0 & 40.0 STR. & 0.0 & 40 & 40.0 STR. \\
\hline \multirow{11}{*}{$\begin{array}{l}\mathrm{f}_{\mathrm{c}}=25.0 \\
\mathrm{MPa} \text { and } \\
\mathrm{a} / \mathrm{d}=3.25\end{array}$} & & 10 & & 104.7 & 59.5 & 146.6 & 56.9 & 140.0 & 100.0 & 100.0 & 100.0 & 100 & 100 & 100 \\
\hline & 1.13 & 20 & & 131.2 & 75.7 & 189.0 & 57.7 & 144.1 & 125.3 & 127.2 & 129.0 & 100 & 100 & 100 \\
\hline & & 30 & & 135.3 & 84.0 & 237.5 & 62.1 & 175.5 & 129.2 & 141.2 & 162.0 & 100 & 100 & 100 \\
\hline & & 10 & & 152.8 & 75.8 & 264.7 & 49.6 & 173.2 & 100.0 & 100.0 & 100.0 & 146.0 & 127.3 & 180.6 \\
\hline & 2.01 & 20 & & 167.2 & 92.0 & 209.5 & 55.0 & 125.2 & 109.4 & 121.4 & 79.1 & 127.5 & 121.5 & 110.8 \\
\hline & & 30 & & 169.5 & 96.3 & 250.7 & 56.8 & 147.9 & 110.9 & 127.2 & 94.7 & 125.3 & 114.7 & 105.6 \\
\hline & 3.14 & 20 & & 219.9 & 108.2 & 230.0 & 49.2 & 104.6 & 103.0 & 107.2 & 70.7 & 167.5 & 142.8 & 121.7 \\
\hline & & 30 & & 203.6 & 109.6 & 269.2 & 53.8 & 132.2 & 95.4 & 108.6 & 82.7 & 150.5 & 130.4 & 113.4 \\
\hline & & 10 & & 257.9 & 126.4 & 356.3 & 49.0 & 138.2 & 100.0 & 100.0 & 100.0 & 246.4 & 212.4 & 243.1 \\
\hline & 4.90 & 20 & & 272.2 & 133.5 & 352.7 & 49.1 & 129.6 & 105.5 & 105.6 & 99.0 & 297.4 & 176.3 & 186.6 \\
\hline & & 30 & & 267.9 & 128.6 & 291.5 & 48.0 & 108.8 & 103.9 & 101.7 & 81.8 & 198.0 & 153.1 & 122.8 \\
\hline
\end{tabular}




\begin{tabular}{|c|c|c|c|c|c|c|c|c|c|c|c|c|c|c|}
\hline \multirow[b]{2}{*}{$\mathbf{f}_{\mathrm{c}}, \mathbf{a} / \mathbf{d}$} & \multirow[b]{2}{*}{$\rho_{t \%}$} & \multirow[b]{2}{*}{ N. R\% } & \multirow[b]{2}{*}{ C. $\mathbf{R} \%$} & \multicolumn{3}{|c|}{ Lateral Load $\left(V_{p}\right)(k N)$} & \multicolumn{2}{|c|}{$\left(V_{\text {pcorr }} / V_{\text {pun }}\right) \times 100$} & \multicolumn{3}{|c|}{$V p / V p_{(N . R 10 \%)} \times 100$} & \multicolumn{3}{|c|}{$V p / V p_{(p t 1.13 \%)} x 100$} \\
\hline & & & & 0.0 & 40.0 & 40.0 STR. & 40.0 & 40.0 STR. & 0.0 & 40.0 & 40.0 STR. & 0.0 & 40 & 40.0 STR. \\
\hline \multirow{11}{*}{$\begin{array}{l}f_{c}=25.0 \\
M P a \text { and } \\
a / d=6.50\end{array}$} & & 10 & & 51.8 & 28.5 & 67.5 & 55.1 & 130.5 & 100.0 & 100.0 & 100.0 & 100 & 100 & 100 \\
\hline & 1.13 & 20 & & 64.2 & 35.4 & 93.6 & 55.2 & 145.9 & 124.0 & 124.3 & 138.6 & 100 & 100 & 100 \\
\hline & & 30 & & 64.1 & 38.4 & 111.6 & 59.9 & 174.2 & 123.8 & 134.7 & 165.3 & 100 & 100 & 100 \\
\hline & & 10 & & 77.7 & 42.0 & 132.0 & 54.1 & 170.0 & 100.0 & 100.0 & 100.0 & 150.1 & 147.4 & 195.5 \\
\hline & 2.01 & 20 & & 83.0 & 39.2 & 102.2 & 47.3 & 123.2 & 106.8 & 93.4 & 77.4 & 129.3 & 110.7 & 109.2 \\
\hline & & 30 & & 82.5 & 43.7 & 124.6 & 53.0 & 151.0 & 106.2 & 104.1 & 94.4 & 128.7 & 113.9 & 111.6 \\
\hline & 3.14 & 20 & & 102.3 & 46.0 & 174.5 & 45.0 & 170.6 & 98.6 & 89.2 & 110.2 & 159.4 & 129.9 & 186.5 \\
\hline & & 30 & & 103.2 & 50.8 & 129.8 & 49.2 & 125.8 & 99.5 & 98.4 & 81.9 & 161.0 & 132.3 & 116.3 \\
\hline & & 10 & & 138.6 & 54.2 & 205.3 & 39.1 & 148.2 & 100.0 & 100.0 & 100.0 & 267.7 & 190.1 & 303.9 \\
\hline & 4.90 & 20 & & 135.9 & 63.4 & 204.0 & 46.6 & 150.2 & 98.1 & 116.9 & 99.4 & 211.8 & 178.9 & 218.0 \\
\hline & & 30 & & 134.6 & 54.3 & 199.6 & 40.3 & 148.2 & 97.2 & 100.2 & 97.2 & 210.1 & 141.4 & 178.8 \\
\hline
\end{tabular}

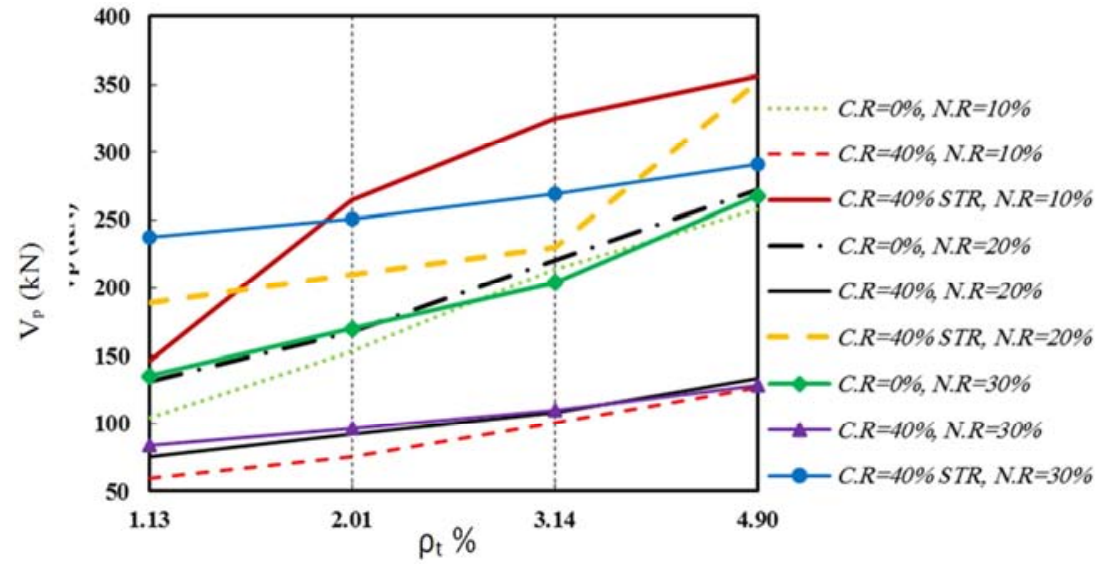

Figure 14. Effect of longitudinal steel ratio on lateral load of RC piers compressive strength 25.0 MPa and aspect ratio a/d=3.25.

\subsubsection{Effect of Aspect Ratio}

Figure 15 and Table 4, by dividing the values of lateral loads at aspect ratio 3.25 to that at $6.50\left(V_{p 3.25} / V_{p 6.50}\right)$, show the effect of aspect ratio on the lateral load resistance of strengthening corroded piers with compressive strength 25 MPa. It was observed that, the lateral load resistance of strengthening corroded piers was greater for piers with aspect ratio 3.25 than that with aspect ratio 6.50 especially, with low axial force ratio $(10.0 \%)$ and low longitudinal reinforcement ratio $(1.13 \%)$. For example, in strengthening corroded piers with axial force ratio $10 \%$, the decrease in aspect ratio from
6.5 to 3.25 leads to the increase in lateral load resistance by $117,100.5,105.5$, and $73.6 \%$ for piers with longitudinal reinforcement ratio $1.13,2.01,3.14$, and $4.90 \%$ respectively

As shown in Table 4, the percentage of lateral load resistance for strengthening corroded piers with longitudinal reinforcement ratio of $4.90 \%$ was decreased by increasing axial force ratio. Unlike piers with longitudinal reinforcement ratio $1.13 \%$, the lateral load resistance was decreased by increasing the axial force ratio from 10.0 to $20.0 \%$, and then was increased by increasing the axial force ratio from 20 to $30 \%$.

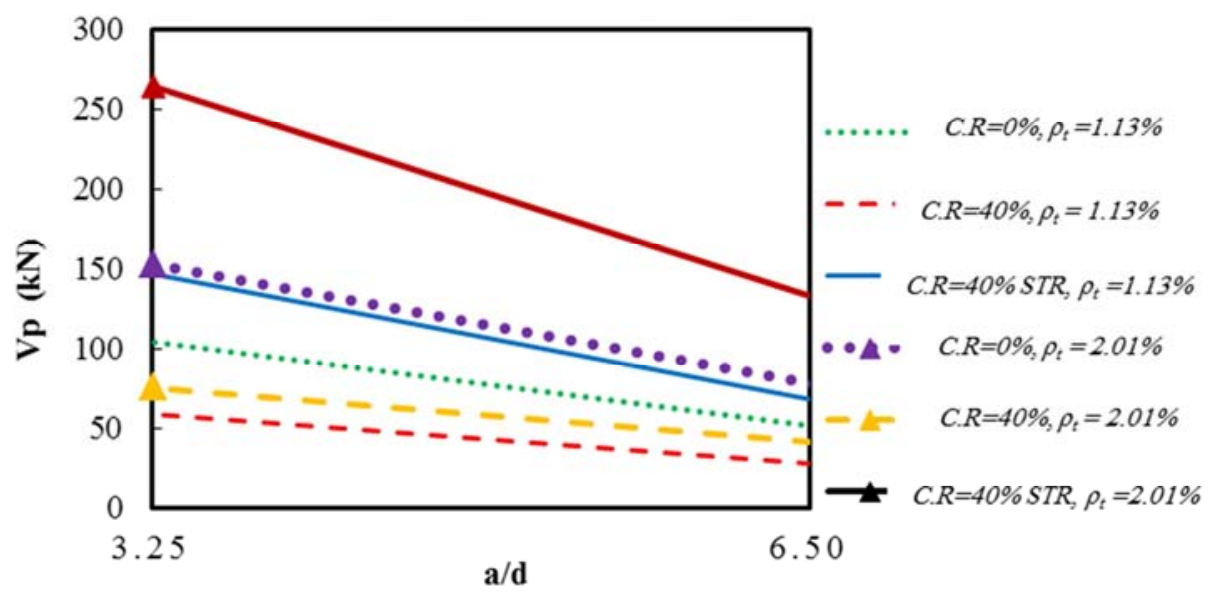

Figure 15. Effect of aspect ratio on lateral load of $R C$ piers with compressive strength $25.0 \mathrm{MPa}$, axial force ratio $10 \%$ and longitudinal steel ratio; $\rho_{t}=1.13$ and $2.01 \%$. 
Table 4. Effect of aspect ratio on lateral loads for piers with compressive strength $25 \mathrm{MPa}$ and axial force ratio 10, 20 and $30 \%$.

\begin{tabular}{|c|c|c|c|c|c|c|c|c|c|}
\hline & & & & Latera & $\left.V_{p}\right)(\mathbf{k N}$ & & $\left(\mathrm{Vp}_{3.25}\right.$ & $\mathbf{x 1 0 0}$ & \\
\hline N. R\% & $\rho_{\mathrm{t} \%}$ & $\mathbf{a} / \mathbf{d}$ & C. R\% & 0.0 & 40 & 40 STR. & 0.0 & 40 & 40 STR. \\
\hline \multirow{8}{*}{10} & \multirow{2}{*}{1.13} & 6.50 & & 51.8 & 28.5 & 67.5 & \multirow{2}{*}{202.3} & \multirow{2}{*}{208.8} & \multirow{2}{*}{217.0} \\
\hline & & 3.25 & & 104.7 & 59.5 & 146.6 & & & \\
\hline & \multirow{2}{*}{2.01} & 6.50 & & 77.7 & 42.0 & 132.0 & \multirow{2}{*}{196.7} & \multirow{2}{*}{180.4} & \multirow{2}{*}{200.5} \\
\hline & & 3.25 & & 152.8 & 75.8 & 264.7 & & & \\
\hline & \multirow{2}{*}{3.14} & 6.50 & & 103.7 & 51.6 & 158.4 & \multirow{2}{*}{205.8} & \multirow{2}{*}{195.5} & \multirow{2}{*}{205.5} \\
\hline & & 3.25 & & 213.4 & 100.9 & 325.5 & & & \\
\hline & \multirow{2}{*}{4.90} & 6.50 & & 138.6 & 54.2 & 205.3 & \multirow{2}{*}{186.1} & \multirow{2}{*}{233.3} & \multirow{2}{*}{173.6} \\
\hline & & 3.25 & & 257.9 & 126.4 & 356.3 & & & \\
\hline \multirow{8}{*}{20} & \multirow{2}{*}{1.13} & 6.50 & & 64.2 & 35.4 & 93.6 & \multirow{2}{*}{204.6} & \multirow{2}{*}{213.9} & \multirow{2}{*}{202.0} \\
\hline & & 3.25 & & 131.2 & 75.7 & 189.0 & & & \\
\hline & \multirow{2}{*}{2.01} & 6.50 & & 83.0 & 39.2 & 102.2 & \multirow{2}{*}{201.6} & \multirow{2}{*}{234.6} & \multirow{2}{*}{204.9} \\
\hline & & 3.25 & & 167.2 & 92.0 & 209.5 & & & \\
\hline & \multirow{2}{*}{3.14} & 6.50 & & 102.3 & 46.0 & 174.5 & \multirow{2}{*}{215.0} & \multirow{2}{*}{235.1} & \multirow{2}{*}{131.8} \\
\hline & & 3.25 & & 219.9 & 108.2 & 230.0 & & & \\
\hline & \multirow{2}{*}{4.90} & 6.50 & & 135.9 & 63.4 & 204.0 & 2003 & 2108 & 1729 \\
\hline & & 3.25 & & 272.2 & 133.5 & 352.7 & 200.3 & 210.8 & $1 / 2.9$ \\
\hline & 1.13 & 6.50 & & 64.1 & 38.4 & 111.6 & 2111 & 3525 & 2127 \\
\hline & 1.13 & 3.25 & & 135.3 & 135.3 & 237.5 & 211.1 & 352.3 & 212.1 \\
\hline & 201 & 6.50 & & 82.5 & 43.7 & 124.6 & 2055 & 2204 & 2012 \\
\hline 30 & 2.01 & 3.25 & & 169.5 & 96.3 & 250.7 & 200.5 & 220.4 & 201.2 \\
\hline & 3.14 & 6.50 & & 103.2 & 50.8 & 129.8 & 197.4 & 2158 & 2074 \\
\hline & 5.14 & 3.25 & & 203.6 & 109.6 & 269.2 & 191.4 & 215.0 & 201.4 \\
\hline & 4.90 & 6.50 & & 134.6 & 54.3 & 199.6 & 199.0 & 236.9 & 146.1 \\
\hline & 4.70 & 3.25 & & 267.9 & 128.6 & 291.5 & 199.0 & & \\
\hline
\end{tabular}

\subsubsection{Effect of Transverse Reinforcement Ratio}

Tables 5 and 6 represent the transverse reinforcement ratio effect on lateral load resistance and modes of failure for strengthening corroded piers with aspect ratio 3.25 and 6.50 , respectively and compressive strength $25.0 \mathrm{MPa}$. From these tables, one can notice that the lateral load resistance of strengthening corroded piers was increased by increasing the ratio of transverse reinforcement from $0.17 \%$ (group1) to $0.25 \%$ (group2) and $0.75 \%$ (group3). For example, strengthening corroded piers with aspect ratio 3.25 , longitudinal reinforcement ratio $3.14 \%$ and axial force ratio $10.0 \%$, the lateral load resistance was increased by $6.1 \%$ and $13.8 \%$ when the ratio of transverse reinforcement was increased from $0.17 \%$ to $0.25 \%$, and $0.75 \%$, respectively. For the same piers, but with aspect ratio 6.50 , the lateral load resistance was increased with $8.0 \%$ and $17.40 \%$ when the ratio of transverse reinforcement was increased from $0.17 \%$ to $0.25 \%$, and $0.75 \%$, respectively. The transverse reinforcement ratio has a major effect on failure modes of strengthening corroded piers. For example, strengthening corroded piers with aspect ratio 3.25 , longitudinal reinforcement ratio $3.14 \%$ and axial force ratio $30.0 \%$, the mode of failure was local buckling and flexure shear when the ratio of transverse reinforcement was increased from $0.17 \%$ to $0.25 \%$, and $0.75 \%$ respectively. For the same piers, but with aspect ratio 6.50 , the mode of failure was local buckling and flexure when the ratio of transverse reinforcement was increased from $0.17 \%$ to $0.25 \%$, and $0.75 \%$ respectively.

It was noted that the percentage of increase in lateral load resistance for strengthening corroded piers with aspect ratio 3.25 , when the ratio of transverse reinforcement was increased from $0.17 \%$ to $0.25 \%$, and $0.75 \%$ for piers with high axial force ratio $(30.0 \%)$ was smaller than that of piers with low axial force ratio (10.0\%), especially when the ratio of transverse reinforcement was increased from $0.17 \%$ to $0.25 \%$. As the buckling load in compression bars control the lateral load resistance.

Table 5. Effect of transverse reinforcement ratio on lateral loads and mode failure for piers with aspect ratio 3.25 and compressive strength $25 \mathrm{MPa}$.

\begin{tabular}{|c|c|c|c|c|c|c|c|c|c|c|c|}
\hline \multicolumn{3}{|c|}{ Input data } & \multicolumn{3}{|l|}{$V p(k N)$} & \multicolumn{3}{|l|}{ Ratio } & \multicolumn{3}{|c|}{ Failure mode } \\
\hline C. $\mathbf{R} \%$ & $\rho_{\mathrm{t}} \%$ & N. R\% & Group (1) & Group (2) & Group (3) & $V p_{2} / \mathbf{V} p_{1}$ & $V p_{3} / V p_{2}$ & $V p_{3} / V p_{1}$ & Group (1) & Group (2) & Group (3) \\
\hline 40 STR. & 1.13 & 10 & 146.6 & 154.1 & 164.0 & 5.1 & 6.4 & 11.9 & L. B. & L. B. & L. B. \\
\hline 40 STR. & 2.01 & 10 & 264.7 & 290.0 & 302.7 & 9.6 & 4.4 & 14.4 & Flx. Sh. & Flx. Sh. & Flx. Sh. \\
\hline 40 STR. & 3.14 & 10 & 325.5 & 345.2 & 370.4 & 6.1 & 7.3 & 13.8 & Flx. Sh. & Flx. Sh. & Flx. Sh. \\
\hline 40 STR. & 4.9 & 10 & 356.3 & 371.3 & 400.8 & 4.2 & 7.9 & 12.5 & Flx. Sh. & Flx. Sh. & Flx. Sh. \\
\hline 40 STR. & 1.13 & 20 & 189.0 & 196.5 & 206.0 & 4.0 & 4.8 & 9.0 & L. B. & L. B. & L. B. \\
\hline 40 STR. & 2.01 & 20 & 209.5 & 212.0 & 222.0 & 1.2 & 4.7 & 6.0 & L. B. & L. B. & L. B. \\
\hline 40 STR. & 4.9 & 20 & 352.7 & 371.8 & 414.1 & 5.4 & 11.4 & 17.4 & Flx. Sh. & Flx. Sh. & Flx. Sh. \\
\hline 40 STR. & 1.13 & 30 & 237.5 & 238.0 & 250.5 & 0.2 & 5.2 & 5.5 & L. B. & L. B. & Flx. Sh. \\
\hline 40 STR. & 2.01 & 30 & 250.7 & 253.0 & 260.0 & 0.9 & 2.8 & 3.7 & L. B. & L. B. & Flx. Sh. \\
\hline 40 STR. & 3.14 & 30 & 269.2 & 269.4 & 321.2 & 0.1 & 19.2 & 19.3 & L. B. & L. B. & Flx. Sh. \\
\hline 40 STR. & 4.9 & 30 & 291.5 & 293.0 & 310.0 & 0.5 & 5.8 & 6.3 & L. B. & L. B. & L. B. \\
\hline
\end{tabular}


Table 6. Effect of transverse reinforcement ratio on lateral loads and mode failure for piers with aspect ratio 6.5 and compressive strength 25 MPa.

\begin{tabular}{|c|c|c|c|c|c|c|c|c|c|c|c|}
\hline \multicolumn{3}{|c|}{ Input data } & \multicolumn{3}{|l|}{$V p(k N)$} & \multicolumn{3}{|l|}{ Ratio } & \multicolumn{3}{|c|}{ Failure mode } \\
\hline C. $\mathrm{R} \%$ & $\rho_{\mathrm{t}} \%$ & N. R\% & Group (1) & Group (2) & Group (3) & $V p_{2} / V p_{1}$ & $V p_{3} / V p_{2}$ & $V p_{3} / \mathbf{V} p_{1}$ & Group (1) & Group (2) & Group (3) \\
\hline 40 STR. & 1.13 & 10 & 67.5 & 80.3 & 99.9 & 18.8 & 24.4 & 47.8 & L. B. & Flexure & Flexure \\
\hline 40 STR. & 2.01 & 10 & 132.0 & 141.1 & 150.1 & 6.9 & 6.4 & 13.7 & Flexure & Flx. Sh. & Flexure \\
\hline 40 STR. & 3.14 & 10 & 158.4 & 171.1 & 186.0 & 8.0 & 8.7 & 17.4 & Flexure & Flx. Sh. & Flexure \\
\hline 40 STR. & 4.9 & 10 & 205.3 & 216.5 & 241.8 & 5.5 & 11.7 & 17.8 & Flexure & Flx. Sh. & Flexure \\
\hline 40 STR. & 1.13 & 20 & 93.6 & 110.8 & 120.0 & 18.4 & 8.3 & 28.2 & Flexure & Flexure & Flexure \\
\hline 40 STR. & 2.01 & 20 & 102.2 & 115.0 & 125.0 & 12.5 & 8.7 & 22.3 & L. B. & Flexure & Flexure \\
\hline 40 STR. & 3.14 & 20 & 174.5 & 191.8 & 212.0 & 9.9 & 10.5 & 21.5 & Flexure & Flx. Sh. & Flexure \\
\hline 40 STR. & 4.9 & 20 & 204.0 & 219.6 & 240.0 & 7.7 & 9.3 & 17.7 & Flexure & Flexure & Flexure \\
\hline 40 STR. & 1.13 & 30 & 111.6 & 125.6 & 132.0 & 12.5 & 5.1 & 18.2 & Flexure & Flexure & Flexure \\
\hline 40 STR. & 2.01 & 30 & 124.6 & 136.0 & 150.0 & 9.2 & 10.3 & 20.4 & Flexure & Flexure & Flexure \\
\hline 40 STR. & 3.14 & 30 & 129.8 & 136.0 & 155.0 & 4.8 & 14.0 & 19.4 & L. B. & Flexure & Flexure \\
\hline 40 STR. & 4.9 & 30 & 199.6 & 215.1 & 237.3 & 7.8 & 10.3 & 18.9 & Flx. Sh. & Flx. Sh. & Flx. Sh. \\
\hline
\end{tabular}

\section{Practical Model to Estimate the Lateral Load Resistance of Corroded
RC Bridge Piers}

Equation 10 was developed to calculate the lateral load resistance for corroded piers as following:

$$
V_{\text {corr }}=\beta_{\text {corr }} V_{c}
$$

Where $V_{\text {corr }}$; the lateral load resistance of corroded RC bridge piers, $\beta_{\text {corr, }}$ lateral load resistance reduction factor concerning corrosion effects. The coefficient $\beta$ corr was used as following:

$$
\beta_{\text {corr }}=\alpha_{1} \alpha_{2} \alpha_{3}
$$

where $\alpha_{l}$; factor consider the corrosion level effect on the lateral load resistance of corroded piers, from analysis of finite element models results, $\alpha_{1}$ can be considered as:

$$
\alpha_{1}=\frac{1}{1+1.45 C \cdot R / 100}
$$

$\alpha_{2}$; factor consider the axial force ratio effect on the lateral load resistance of corroded piers. After analyzing the results of finite element models, $\alpha_{2}$ can be used as:

$$
\alpha_{2}=\frac{1}{1+0.24 N \cdot R / 100}
$$

$\alpha_{3}$; factor consider the longitudinal reinforcement ratio effect on the lateral load resistance of corroded piers. $\alpha_{3}$ can be used as:

$$
\alpha_{3}=\frac{1}{1+6.0 \rho_{t} / 100}
$$

$V_{c}$; The lateral load resistance of un-corroded RC bridge piers.

$$
\mathrm{V}_{\mathrm{c}}=\min .\left(\mathrm{V}_{\mathrm{n}}, \frac{M_{n}}{a}\right)
$$

Where $V_{n}$; Shear strength of un-corroded bridge piers, $a$; Shear span of study pier, $M_{n}$; Nominal moment of resistance of section in plastic hinge zone. Figure 16 shows the comparison between results of FE and Equation 10. From the calculated percentage of error and fitting curve, there is a good agreement between results.

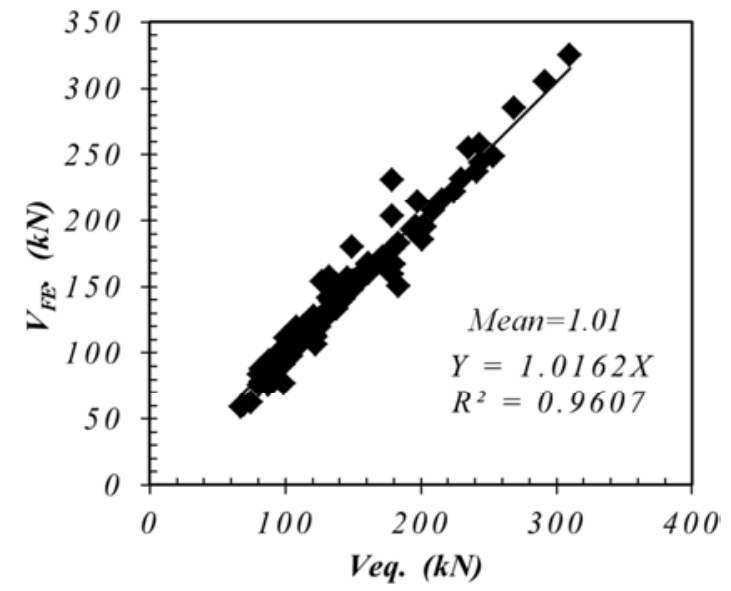

Figure 16. Comparisons between the lateral load resistances calculated by FE analyses and Equation 10 for piers with aspect ratio 3.25 and compressive strength 25.0 MPa.

\section{Conclusions}

Based on the finite element analysis and dissections of results, conclusions can be summarized:

1. The lateral load resistance was decreased by increasing corrosion level from 0.0 to $40 \%$ and was increased by strengthening of piers with corrosion level $40.0 \%$ by replacing concrete cover by UHPFRC jacketing with $40.0 \mathrm{~mm}$ thickness.

2. For piers with a high longitudinal reinforcement ratio of $4.90 \%$ and aspect ratio 3.25 , the percentage of lateral load resistance of strengthening corroded pier was decreased by the increase in axial force ratio.

3. The percentage of lateral load resistance of strengthening corroded piers with aspect ratio 6.50 was smaller than that of piers with aspect ratio 3.25, especially with low longitudinal reinforcement ratio 1.13 and $2.01 \%$ and low axial force ratio 10 and $20 \%$.

4. The lateral load resistance of strengthening corroded piers was increased by the increase in axial force ratio for piers with a low longitudinal reinforcement ratio.

5. The lateral load resistance of strengthening corroded 
piers was increased by the increase in axial force ratio for piers with aspect ratio 6.50 more than that for piers with aspect ratio 3.25 .

6. The effect of the increase in longitudinal reinforcement ratio on increasing the lateral load resistance percentage of strengthening corroded piers was decreased with increasing of axial force ratio.

7. The percentage of the increase in lateral load resistance of strengthening corroded piers with aspect ratio 6.50 was greater than that of piers with aspect ratio 3.25 and a longitudinal reinforcement ratio of $4.90 \%$. However, the percentage of the increase in lateral load resistance of strengthening corroded piers with aspect ratio 6.50 was lower than that of piers with aspect ratio 3.25 with a longitudinal reinforcement ratio of 2.01 and $3.14 \%$.

8. The lateral load resistance of strengthening corroded piers was greater for piers with aspect ratio 3.25 than that with aspect ratio 6.50 especially, with low axial force ratio $10 \%$ and a low longitudinal reinforcement ratio of $1.13 \%$.

9. The lateral load resistance of strengthening corroded piers was increased by the increase in ratio of transverse reinforcement from $0.17 \%$ to 0.25 and $0.75 \%$ and transverse reinforcement ratio have a major effect on failure modes of strengthening corroded piers.

10. The lateral load resistance for corroded piers can be calculated by using the developed following equation: $V_{\text {corr }}=\beta_{\text {corr }} V_{c}$.

The FEA models and the proposed practical model can be used by engineers practice to estimate the lateral capacity of corroded RC bridge piers. The results of this research suggest that this technique could be applied for existing concrete bridge exposed in the marine environment whereas, the concentration of corrosive chlorides are high and can also use for any shape of a column and this technique allows keeping the initial dimension of the column.

\section{References}

[1] Tapan \& Aboutaha, (2008). Strength evaluation of deteriorated reinforced concrete bridge columns. Syracuse University, Syracuse, Ny.

[2] Akkaya C. G., (2012). Seismic behavior of RC columns with corroded plain and deformed reinforcing bars. Doctor of Philosophy Thesis, Istanbul Technical University, Istanbul, Turkey.

[3] Ma Y, Che Y, Gong J., 2012. Behaviour of corrosion damaged circular reinforced concrete columns under cyclic loading. Construction and Building Materials, No. 29, 548-556.

[4] Shihata A., 2011. CFRP strengthening of RC beams with corroded lap splice steel bars. Master of Applied Science Thesis. University of Waterloo, Waterloo, Canada.

[5] Ou Y. C, Tsai L. L, Chen H. H., 2012. Cyclic performance of large-scale corroded reinforced concrete beams. Earthquake Engineering and Structural Dynamics, No. 41, 593-604.

[6] Ran Feng, Yanwen Li, Ji-Hua Zhu, \& Feng Xing, (2021).
Behavior of corroded circular RC columns strengthened by CFRCM under cyclic loading. Engineering Structures, 226.

[7] Haijun Zhoua, Yanan Xu, Yanrong Peng, Xuebing Liang, Dawang Li, \& Feng Xing, (2020). Partially corroded reinforced concrete piers under axial compression and cyclic loading: An experimental study. Engineering Structures, 203.

[8] Fib Bulletin No. 24, (2003). Seismic Assessment and Retrofit of Reinforced Concrete Buildings. State-of-Art Report, Lausanne.

[9] Martinola, G., Meda, A., Plizzari, G. A., \& Rinaldi, Z., (2010). Strengthening and repair of R/C beams with fiber-reinforced concrete. Cement and Concrete Composites, 32 (9), 731-739.

[10] Beschi, C., Meda, A., \& Riva, P., (2009). High performance fiber reinforced concrete jacketing in a seismic retrofitting application. Paper presented at the ATC \& SEI conference on Improving the Seismic Performance of Existing Buildings and other Structures.

[11] Wanga, W., Liub, J., Agostini, F., Davy, CA, Skoczylas, F., \& Corvez, D., (2014). Durability of an ultra-high performance fiber reinforced concrete (UHPFRC) under progressive aging. Cem Concr Res 55, 1-13.

[12] Meda, A., \& Mostosi, S., (2016). Corroded RC columns repair and strengthening with high performance fiber reinforced concrete jacket. Materials and Structures, 49, 1967-1978.

[13] Tastani, S., \& Pantazopoulou, S. J., (2005). Recovery of seismic resistance in corrosion-damaged reinforced concrete through FRP jacketing. International Journal of Materials and Product Technology, 23 (3/4), 389-415.

[14] Lee, C., Bonacci, J., Thomas, M., Maalej, M., Khajenpour, S., Hearn, N., Pantazopoulou, S., \& Sheikh, S., (2000). Accelerated corrosion and repair of r. c. columns using CFRP sheets. Canadian J. of Civil Engineering, NRC, Special Issue on ISIS-Canada, 27 (5), 949-959.

[15] Pantazopoulou, S. J., Bonacci, J. F., Sheikh, S., Thomas, M. D A., \& Hearn, N., (2001). Repair of corrosion-damaged columns with FRP wraps. ASCE J. of Composites for Construction, 5 (1), 3-11.

[16] Bonacci, J., \& Maalej, M., (2000). Externally bonded fiber reinforced polymer for rehabilitation of corrosion damaged concrete beams. ACI Structural J., 97 (5), 703-711.

[17] Debaiky, A., Green, M., \& Hope, B., (2002). Carbon fiberreinforced polymer wraps for corrosion control and rehabilitation or r. c. columns. ACI Material J., 99 (2), 129 137.

[18] Tastani, S., \& Pantazopoulou, S., (2004). Experimental evaluation of FRP jackets in upgrading RC corroded columns with substandard detailing. Elsevier Engineering Structures, 26 (6), 817-829.

[19] ANSYS Users' Manual, Release 17.0. ANSYS, INC., Canonsburg, Pennsylvania; (2017).

[20] ACI 374.2R-13, (2013). Guide for testing reinforced concrete structural elements under slowly applied simulated seismic loads. ACI Committee 374.

[21] Coronelli, D., \& Gambarova P., (2004). Structural assessment of corroded reinforced concrete beams: modeling guidelines. J. Struct. Eng., 130, 1214-1224. 
[22] Cape, M., (1999). Residual service-life assessment of existing $\mathrm{R} / \mathrm{C}$ structures (MS thesis). Chalmers Univ. of Technology, Goteborg (Sweden) and Milan Univ. of Technology (Italy), Erasmus Program.

[23] Molina, F. J., Alonso, C., \& Andrade C., (1993). Cover cracking as a function of rebar corrosion: part 2-numerical model. Mater. Constr., 26, 532-548.

[24] Hanjari, K. Z., Kettil, P., \& Lundgren, K., (2011). Analysis of mechanical behavior of corroded reinforced concrete structures. ACI Struct. J. 108, 532-541.

[25] ACI 318-14 A, (2014). Building code requirements for structural concrete (ACI 318-14) and commentary. American Concrete Institute, Farmington Hills, Mich.

[26] Du, Y. G., Clark L. A., \& Chan A. H. C., (2005). Effect of corrosion on ductility of reinforcing bars. Magazine of Concrete Research, 57 (7), 407-419.

[27] Salim, R., \& Murat, S., (1992). Strength and ductility of confined concrete. Journal of Structural Engineering, 118 (6).

[28] Maaddawy, T. E., Soudki, K., \& Topper, T., (2005). Analytical model to predict nonlinear flexural behavior of corroded reinforced concrete beams. ACI Struct. J., 102, 550-559.

[29] Design of concrete structures: CEB-FIP Model-Code 1990, London, UK (1990).
[30] Park, R, (1995). Simulated seismic load tests on reinforced concrete elements and structures. In: 10th World Conference on Earthquake Engineering, Balkema, Rotterdam, Netherlands.

[31] Meda, A., Mostosi, S., Rinaldi, Z., \& Riva P., (2014). Experimental Evaluation of The Corrosion Influence on The Cyclic Behavior of RC Columns. Eng. Struct., 76, 112-123.

[32] Li, J., Gong, J., \& Wang, L., (2009). Seismic behavior of corrosion - damaged reinforced concrete columns strengthened using combined carbon fiber-reinforced polymer and steel jacket. Journal of Construction and Building Materials, 23, 2653-2663.

[33] Wang, X., (2003). Research of seismic performance and hysteretic mode of corroded reinforced concrete members. Master, Xi' an University of Architecture and Technology.

[34] Goksu, C., (2012). Seismic behavior of RC columns with corroded plain and deformed reinforcing bars. PhD, Istanbul Technical University, Turkey.

[35] Mohamed Husain, Heba A. Mohamed \& Sayed Ahmed, (2017). Evaluation of non-conforming corroded bridge piers exposed to seismic loads. International Journal of Engineering and Innovative Technology, Vol. 7, 14-24. 